Szabados Máté',2, Csákó Zsófia', Bohumil Kotlík³, Helena Kazmarová3, Anna Kozajda, Anja Jutraz ${ }^{5}$ Andreja Kukec $^{5}$, Peter Otorepec ${ }^{5}$, Arianna Dongiovanni ${ }^{6}$, Andrea Di Maggio ${ }^{6}$, Stefano Fraire ${ }^{6}$, Szigeti Tamás

${ }^{1}$ Nemzeti Népegészségügyi Központ, Budapest / National Public Health Center, Budapest, Hungary

${ }^{2}$ Környezettudományi Doktori Iskola, Eötvös Loránd Tudomány Egyetem, Budapest / Doctoral School of Environmental Sciences, ELTE, Budapest, Hungary

${ }^{3}$ National Institute of Public Health, Prague, Czech Republic

${ }^{4}$ Nofer Institute of Occupational Medicine, Łódź, Poland

${ }^{5}$ National Institute of Public Health, Ljubljana, Slovenia

${ }^{6}$ LINKS Foundation, Turin, Italy

\title{
Általános iskolák beltéri levegöminösége Közép-Európában - Az InAirQ projekt
}

\author{
Indoor air quality in Central European primary school buildings - The InAirQ
}

project

\section{Összefoglalás}

A Nemzeti Népegészségügyi Központ konzorciumvezetőként részt vett az InAirQ elnevezésü nemzetközi projektben, melynek célja, többek között, a beltéri levegőminőség vizsgálata általános iskolákban, illetve olyan akciótervek kidolgozása, melyekkel a beltéri levegő minősége javítható. Egy kampány keretében összesen hatvannégy általános iskola egy-egy osztálytermét vizsgáltuk a Cseh Köztársaságban ( $n=12)$, Magyarországon ( $n=16)$, Olaszországban $(n=12)$, Lengyelországban $(n=12)$ és Szlovéniában $(n=12)$. A belés kültéri levegőminőség vizsgálatára irányuló mintavételeket a 2017/2018-as fütési időszakban végeztük a kiválasztott iskolaépületeknél. A légszennyezők közül meghatároztuk számos aldehid és illékony szerves vegyület, a kisméretű aeroszol részecskék $\left(\mathrm{PM}_{25}\right)$, a szén-dioxid és a radon koncentrációját. A felmérés ideje alatt néhány fizikai paraméter (hőmérséklet, relatív páratartalom) alakulását is nyomon követtük. Jelentős eltéréseket tapasztaltunk számos légszennyező anyag esetén a felmérésben résztvevő országok között. A benzol koncentrációja a vizsgált iskolák 37\%-ában meghaladta az Európai Bizottság által, a kültéri környezetre meghatározott éves határértéket $\left(5 \mathrm{\mu g} / \mathrm{m}^{3}\right)$. Azonban a beltéri benzol koncentráció minden esetben a kültéri értékkel közel azonos volt, így kijelenthetö, hogy a benzolnak nincs jelentős beltéri forrása. A formaldehid koncentrációja beltéren minden esetben meghaladta a kültéri értéket, azonban egyik esetben sem érte el az Egészségügyi Világszervezet (WHO) által javasolt irányértéket $\left(100 \mu \mathrm{g} / \mathrm{m}^{3}\right)$. A $\mathrm{PM}_{2.5}$ tömegkoncentráció az iskolák 56\%-ában meghaladta a WHO által megállapított 24 órás irányértéket $\left(25 \mathrm{\mu g} / \mathrm{m}^{3}\right)$, illetve az iskolák $85 \%$-ában az éves $\left(10 \mu \mathrm{g} / \mathrm{m}^{3}\right)$ irányértéket meghaladó értékeket mértünk. A vizsgált osztálytermekben a szén-dioxid koncentrációja több esetben is magas volt (az átlag meghaladta a 1000 ppm értéket), jelezve az elégtelen szellőztetést. A komfortérzetet befolyásoló paraméterek közül a relatív páratartalom sok esetben nagyon alacsony volt. A radon koncentrációja 100 Bq/m3 körül mozgott, kivéve néhány osztálytermet Magyarországon, Lengyelországban és Szlovéniában.

Kulcsszavak: gyerekek, környezetegészségügy, beltéri levegőminőség, InAirQ 


\section{Abstract}

The National Public Health Center participated as a consortium leader in the international project called InAirQ, aiming to investigate the indoor air quality (IAQ) and to take actions to improve the indoor environment in primary school buildings. In total, sixty-four primary school buildings were investigated in the Czech Republic $(n=12)$, Hungary $(n=16)$, Italy $(n=12)$, Poland $(n=12)$, and Slovenia $(n=12)$. The air quality was investigated during the heating period of 2017/2018. The concentration of volatile organic compounds, aldehydes, $P M_{2.5}$ mass, carbon dioxide, radon were investigated. Physical parameters (e.g. temperature, relative humidity) were also monitored. Significant differences were identified for the majority of the investigated IAQ parameters across the countries. The concentration of benzene was higher than $5 \mu \mathrm{g} \mathrm{m}^{-3}$, the annual limit value set for the ambient air by the European Commission, in $37 \%$ of the investigated school buildings. It must be noted that the concentration of benzene indoors was similar to that obtained for outdoors in all cases which indicates the lack of indoor sources. The concentration of formaldehyde was always higher indoors than outdoors, although the concentration of formaldehyde never reached the WHO guideline $\left(100 \mu \mathrm{g} \mathrm{m} \mathrm{m}^{-3}\right)$. The $P M_{25}$ mass concentration values exceeded the 24- $h$ and annual guideline values set by the World Health Organization in 56 and $85 \%$ of the cases, respectively. The carbon-dioxide concentration was high in the majority of the classrooms (the average value exceeded $1000 \mathrm{ppm}$ ), indicating the inappropriate ventilation. Among the parameters affecting the comfort of the students, the relative humidity was very low in many cases. The radon level

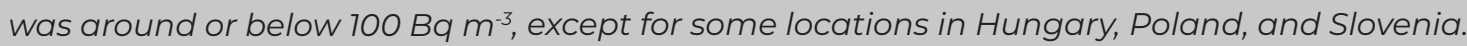

Keywords: children, environmental health, indoor air quality, InAirQ

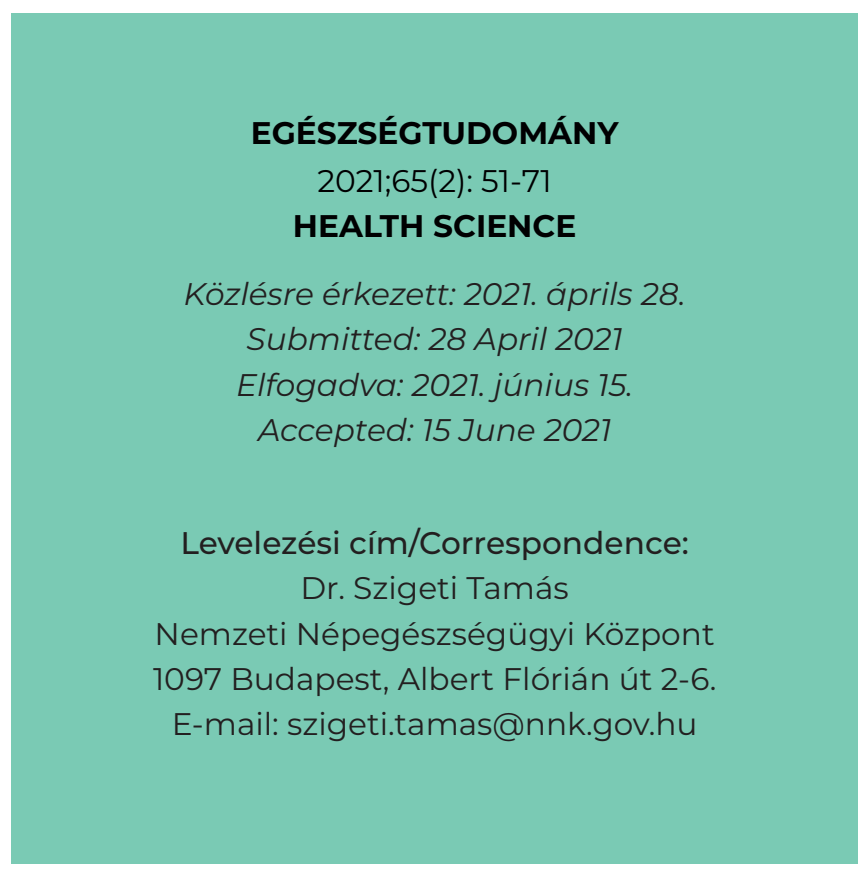


Az első, nagyléptékű nemzetközi projekt a HESE (Health Effects of the School Environment; 2004 2005) felmérés volt, melynek keretében Európa öt országában, huszonegy általános iskolát vizsgáltak. A felmérés nem csak az osztálytermek beltéri levegőminőségének jellemzésére irányult, hanem vizsgálták a légszennyezők gyermekek egészségére gyakorolt hatását is. Számos, beltéri levegőminőséggel kapcsolatos problémát azonosítottak. A tantermeket a nem megfelelő szellőztetés, az alacsony légcsere jellemezte, mely a beltéri légszennyezők feldúsulásához vezetett ${ }^{3}$. Az AIRMEX (European Indoor Air Monitoring and Exposure Assessment) projekt célul tüzte ki, hogy vizsgálja a beltéri levegőminőséget, és a hozzá köthető lehetséges egészségkockázatokat. A felmérés során 9 ország iskoláiban vizsgálták az illékony szerves vegyületeket 2003 és 2008 között. Eredményeiket összegezve, felhívták a figyelmet arra, hogy további, átfogóbb kutatások szükségesek a légszennyezők és azok egészséghatásainak kimutatására ${ }^{4,5}$. A SEARCH (School Environment and Respiratory Health of Children; 2006 - 2013) kezdeményezést az olasz Környezet- és Tájvédelmi, valamint Tengerügyi Minisztérium támogatta. Tíz ország közremüködésével tovább vizsgálták az iskolai környezetet és a gyermekek légzőszervi egészségét. A SEARCH projektet két lépésben hajtották végre. Az első fázisban (2006-2009) egy átfogó adatbázis készült számos légszennyező anyag bel- és kültéren mért koncentrációjáról. A második fázisban (2010-2013), a figyelem az iskolaépületek energiafelhasználásának és az építőanyagok gyermekekre gyakorolt egészséghatásainak értékelésére irányult. Ennek jegyében javaslatokat fogalmaztak meg a beltéri levegőminőség javítására, valamint az energiahatékonyság növelésére ${ }^{6,7}$. A SINPHONIE (Schools Indoor Pollution and Health - Observatory Network in Europe; 2010 - 2012) projekt Európa legnagyobb léptékű felmérése, melynek keretében 23 európai országban egységes módszerrel vizsgálták az iskolai környezetet és a 7-11 éves korú gyermekek egészségét ${ }^{8,9}$. A projekt keretében jelenlegi és jövőbeni szabályozással kapcsolatos útmutatókat dolgoztak ki az egészséges iskolai környezet kialakítása céljából. A javaslatok kidolgozásánál tekintettel voltak a kültéri környezetre, a szellőztetésre, az építési stratégiákra, az építőanyagokra, a fogyasztási cikkekre, valamint a figyelemfelkeltésre és képzésre is nagy hangsúlyt fektettek.

Nemzetközi projekteken kívül számos nemzeti tanulmány is készült a témában, melyek középpontjában a beltéri levegőminőséghez kapcsolódó egészséghatások vizsgálata és a bizonyítékok feltárása állt10-13.
Az iskolaépületek beltéri levegőminőségével kapcsolatban továbbra is számos probléma megoldatlan a gyakorlatban, az osztálytermekben egyes légszenynyezők koncentrációja magasabb lehet, mint a kültéri értékek. Számos ország nem rendelkezik mérési adatokkal az iskolaépületek épített beltéri környezetéről, annak ellenére, hogy régóta a figyelem központjában áll a középületek beltéri levegőminőségének felmérése és javítása. Továbbá, jelenleg még nincs egyetértés abban, hogy miként szabályozzák a beltéri levegőminőséget nemzetközi szinten. A beltéri levegőminőséggel és a gyermekek egészségével kapcsolatos ismeretek bővítése érdekében az InAirQ projekt célul tűzte ki a beltéri légszennyező anyagok azonosítását és a hozzá köthető egészségkockázatok azonosítását az általános iskolák épületeiben. További cél volt az InAirQ projekt keretében a beltéri levegőminőség javítását célzó nemzeti akcióterv kidolgozása.

\section{Az InAirQ projekt}

A Nemzeti Népegészségügyi Központ konzorciumvezetőként irányította a 2016. július 1-jén elinduló InAirQ (Transnational Adaption Actions for Integrated Indoor Air Quality Management) elnevezésú nemzetközi projektet, mely célul túzte ki többek között a beltéri levegőminőség vizsgálatát általános iskolákban, illetve olyan akciótervek kidolgozását, melyekkel a beltéri levegő minősége javítható. A projekt során öt közép-európai ország (Csehország, Lengyelország, Magyarország, Olaszország, Szlovénia) hatvannégy általános iskolájában vizsgáltuk a beltéri és kültéri levegő minőségét. A beltéri légszennyező anyagok közül mértük az aldehidek, illékony szerves vegyületek, kisméretü aeroszol részecskék $\left(\mathrm{PM}_{2.5}\right)$, radon és szén-dioxid koncentrációját. A felmérés ideje alatt a komfortérzetet befolyásoló néhány fizikai paraméter (hőmérséklet, relatív páratartalom) alakulását is nyomon követtük. A levegőminőséget meghatározó paraméterek mérésén kívül kérdőíves felmérést is végeztünk. A kérdőív segítségével információt gyűjtöttünk az iskolás gyermekek légzőszervi és allergiás tüneteiről, illetve az otthoni környezetükről. Felmértük az iskolaépület és az osztályterem tulajdonságait (pl.: iskolák elhelyezkedése, padlóburkolat típusa, épület kora, stb.) ellenőrzőlisták segítségével. Magyarországon a felmérés humán biomonitoring vizsgálattal is kiegészült.

Nagy hangsúlyt kapott a szemléletformálás is a projektben, ennek céljából oktatási anyagok, ismeretterjesztő előadások, szemléletformáló anyagok kerültek 
kidolgozásra a pedagógusok, az iskolai fenntartók és az építészek részére. A tanulókorban lévő gyerekek szemléletformálása is a projekt egyik kiemelt jelentőségü célja volt. Az InAirQ projekt alatt a Nemzeti Népegészségügyi Központ egy rajz-, fotó-, plakát és videó pályázatot hirdetett meg általános iskolás gyermekek számára, melynek témája az egészséges levegő volt. Mivel az iskoláskor a társadalomba beilleszkedés kezdete, ezért az időben elsajátított, egészséggel kapcsolatos ismeretek és szokások jelentik nemcsak a saját, hanem mások egészségének helyes irányba történő fejlődését is.

Az iskolaépületek beltéri levegőminőség vizsgálatának fő célja a meglévő problémák azonosítása, melyek alapot szolgáltatnak a beltéri levegő minőségének javítását célzó cselekvési tervek kidolgozásához. A beltéri levegőminőség javítására irányuló intézkedéseket több nemzetközi szervezet ( $\mathrm{pl}$. WHO) is kiemelte, és számos ajánlást fogalmaztak meg már korábbi nemzetközi projektek (pl. SINPHONIE) az elmúlt évtizedben. Sok tantermet azonban továbbra is rossz beltéri levegőminőség jellemez, ami azt jelzi, hogy a javítására irányuló újabb beavatkozási tervek kidolgozása és tesztelése még mindig szükséges. Ennek megfelelően a projektben három tervet dolgoztak ki a mintavételi kampány során azonosított problémák alapján. Így Csehországban, Magyarországon és Lengyelországban három különböző kísérletet teszteltek a beltéri levegő minőségének javítására. A Cseh Köztársaságban helyes takarítási és szellőztetési gyakorlatokat alkalmaztak egy forgalmas út mellett található iskolában. Magyarországon egy légtisztító berendezés hatásfokát vizsgálták egy kiválasztott iskola osztálytermében, míg Lengyelországban levegőminőséget mérő monitorokkal láttak el osztálytermeket, hogy valós idejű tájékoztatást nyújtsanak a tanároknak a jelenlegi beltéri levegőminőségröl. A tanulmányokból kiderült, hogy a fő légszennyező anyagok koncentrációja csökkenthető az alkalmazott kísérleti módszerekkel.

\section{Mintavételi/helyszíni mérési kampány}

Az iskolaépületek kiválasztása előre meghatározott szempontok alapján történt. Elsődleges szempont volt, hogy a kiválasztott épületek reprezentálják az adott ország iskolaépületeit, azaz a kiválasztás során figyelembe vettük az alkalmazott építési technológiát és az épületek korát is. A szellőztetés típusa jelentősen befolyásolja a beltéri levegő minőségét. Mivel
Közép-Európában a természetes szellőztetés a legygyakoribb, ezért főleg olyan iskolaépületeket választottunk, melyekben nem volt mechanikus szellőztető rendszer. A beltéri levegő alapvetően a kültéri levegőből származik. Egy belső térnek állandó kapcsolata van a kültéri levegővel, így a kültér szennyező anyagai jelen vannak a beltérben is. Ennek okán az iskolaépületek kiválasztásnál figyelembe vettük azok elhelyezkedését és törekedtünk a különböző környezetekben található épületek kiválasztására. Az osztálytermek kiválasztása szintén elöre meghatározott szempontrendszer alapján történt. Minden iskolaépületben egy tanteremet vizsgáltunk, mely a legjobban reprezentálta a többi osztálytermet az épületen belül. A kiválasztási eljárás során azt is figyelembe vettük, hogy a diákok a tanóráik legnagyobb részét a felmérésbe bevont osztálytermekben töltsék.

Összesen hatvannégy általános iskola épületének egy-egy osztálytermét vizsgáltuk a Cseh Köztársaságban ( $n=12$ ), Magyarországon ( $n=16)$, Olaszországban ( $n=12$ ), Lengyelországban ( $n=12$ ) és Szlovéniában ( $n$ = 12). A bel- és kültéri levegőminőség vizsgálatára irányuló mintavételeket a 2017/2018-as fütési időszakban (2017. november 6-tól 2018. április 6-ig) 5 egymást követő tanítási napon végeztük épületenként. A levegőminőséget meghatározó kémiai és fizikai paraméterek vizsgálata hétfő reggeltől péntek délutánig tartott. A kitettség pontosabb becslése érdekében a mintavétel és a helyszíni mérések kiértékelése egy 6 8 órás időintervallumra vonatkozott iskolától függően, vagyis a mintavételt és a mérési adatok kiértékelését a tanítási nap hosszához igazítottuk. A felmérés során olyan kémiai szennyezőket vizsgáltunk, melyek a korábbi, nemzetközi vizsgálatokban is szerepeltek. Meghatároztuk 10 illékony szerves vegyület, 5 aldehid, $\mathrm{PM}_{2.5}$ méretfrakció, $\mathrm{CO}_{2}$ és a radon koncentrációját, valamint néhány fizikai paraméter (hömérséklet, relatív páratartalom) alakulását is nyomon követtük.

A mintavételi eszközöket az ISO 16000-1:2004 szabványnak megfelelően a padlótól körülbelül 0,8 - 1 m magasságban telepítettük, mely megfelel az ülő gyermekek légzési zónájának. Amikor arra lehetőség volt, azokat az osztályterem közepén, de minden esetben a faltól vagy ablaktól egy méter távolságban helyeztük el. A beltéri vizsgálattal párhuzamosan minden épületnél kültéri mérések is folytak azonos mérőmüszerekkel és mintavételi eszközökkel. A kültéri mintavételi pont kiválasztásánál figyelembe vettük, hogy a mintavételi eszközök a vizsgált tanteremmel azonos magasságban legyenek elhelyezve. Azokban az iskolákban, me- 
lyek mechanikus szellőztetőrendszerrel voltak ellátva, ott a mintavételi pontot a szellőzőrendszer légbeömlőjénél jelöltük ki.

Az illékony szerves vegyületek és aldehidek mintavételezésére Radiello ${ }^{\circledR}$ típusú diffúziós mintavevőket alkalmaztunk. A mintavétel minden tanítási napon az első óra előtt kezdődött és az utolsó óra befejeztével ért véget, amikor a diákok elhagyták a tantermet. Ennek eredményeképpen a mintavételi idő a teljes hét folyamán 30 és 40 óra között volt, az osztályterem foglaltságától függően. Az illékony szerves vegyületek megkötésére adszorpciós mintavevő csöveket (RadielIO $\left.{ }^{\circledR}\right)$ használtunk. A komponensek meghatározását az ISO 16017-2: 2003 szabvány szerint TD-GC-MS/MS rendszerrel SIM módban végeztük. Aldehidek mintavételezésére 2,4-dinitrofenilhidrazinnal bevont szilikagélt alkalmaztunk (Radiello®), mely reagálva a karbonilcsoporttal stabil, 2,4-dinitrofenilhidrazon származékot eredményez. Acetonitriles leoldást követően a kapott oldatokat HPLC-DAD rendszerrel, 360 nm hullámhoszszon vizsgáltuk az ISO 16000-4:2011 szabványnak megfelelően.

A kisméretű aeroszol részecskék $\left(P M_{2.5}\right)$ mintavétele alacsony térfogatáramú mintavevőkkel történt. A mintavétel során a megmintázandó levegőt egy alacsony térfogatáramú pumpa segítségével, egy kvarcszálas szűrőt ( $\varnothing 37$ vagy 47 mm, Pallflex® Tissuquartz) tartalmazó mintavevő egységen (impaktor) áramoltattuk keresztül. A mintavételhez használt pumpa 10 I/perces térfogatáramát egy rotaméter segítségével állítottuk be. A térfogatáramot minden egyes mintavételi nap elején és végén ellenőriztük. A körülbelül $5 \times 8$ órás mintavételi periódus végén, a mintát egy speciális szűrőtartó tokban szállítottuk és mélyhütőben tároltuk a tömegmérésig. Mintavételt megelőzően a szerves komponensek eltávolítása érdekében a szúrőket $550^{\circ} \mathrm{C}$-on 8 órán át izzítottuk. Ezután a szűrőket egy akklimatizált helyiség ben kondicionáltuk legalább 48 órán át $20 \pm 1^{\circ} \mathrm{C}$-on és $50 \pm 5 \%$ relatív páratartalom mellett, majd egy 1 mg-os leolvashatósággal bíró mikromérleg (Mettler Toledo XPE26) segítségével meghatároztuk a tömegét. A kondicionálást a mintavételt követően is elvégeztük.

A radon mérésére egy CR-39 típusú passzív nyomdetektort (RSKS type, Radosys Kft., Budapest, Hungary) helyeztünk ki 3 hónapos időszakra a tanulmányba bevont iskolák egy-egy osztálytermébe. A mintavételt követően a nyomdetektorokat alumíniumfóliába csomagoltuk, majd müanyag zacskóba helyeztük és az ISO 11665-4: 2012 szabványnak megfelelően történt az elemzése.
A hőmérsékletet, relatív páratartalom és a $\mathrm{CO}_{2}$ méréseket beltéren és kültéren egyaránt különböző, kalibrált múszerekkel (Testo 174H, Testo 435, TSI 7545, Green Eye) végeztük. Az online mintavételezéssel nagy időbeli felbontással lehet meghatározni a paraméterek változását. Jelen tanulmányban az adatrögzítés 1-3 perces időközönként történt.

A mintavételt követően a partnerországok a mintavevő eszközöket (Radiello, kvarcszálas szűrő, CR-39 nyomdetektor) hütött csomagolásban küldték a Nemzeti Népegészségügyi Központba. Az összes laboratóriumi vizsgálatot a Nemzeti Népegészségügyi Központban végeztük el, mely a projektben a központi laboratórium szerepét töltötte be.

\section{Adatfeldolgozás}

Az adatok statisztikai elemzését a STATISTICA szoftvercsomaggal (STATISTICA 7.1 szoftver; Statsoft, Inc.) végeztük. Az adatok elemzése során általában szükség van az eloszlás vizsgálatára. Több olyan statisztikai próba is van, melyeket csak akkor végezhetünk el, ha a változóink adatai ismert eloszlásúak, emiatt a normalitás vizsgálatára a Shapiro-Wilk tesztet alkalmaztuk. Ha nem normális az eloszlás, csak nem-paraméteres próbát végezhetünk. Annak eldöntésére, hogy egy adott országhoz tartozó levegőminőségi paraméterek mediánjai között szignifikáns eltérés mutatkozik-e, Kruskal-Wallis és Mann-Whitney-U statisztikai próbát alkalmaztunk. Ellenkező esetben, ha a normalitás vizsgálat során az adatok normális eloszlást mutattak, akkor varianciaanalízist (ANOVA) és kétmintás t-próbát alkalmaztunk. A torzítás csökkentése érdekében a kimutatási határ (LOD) alatti értékeket LOD/2 értékekkel helyettesítettük. Az LOD és a meghatározási határ (LOQ) közötti értékek esetében a laboratórium által megadott nyers koncentráció értékeket tartottuk meg a statisztikai elemzésekhez.

\section{Eredmények és következtetések}

\section{A vizsgálatba bevont iskolaépületek és osztályter- mek jellemzöi}

A felmérésben alkalmazott két ellenőrzőlista az iskolaépület és a vizsgált tanterem általános jellemzőin kívül a bel- és kültéri levegőminőséget befolyásoló tényezőkre vonatkozott. A kiválasztott iskolákról elmondható, hogy az épületek több mint fele ( $n=40 ; 64 \%$ ) 1950 
és 2000 között épült, csak két épület létesült 2000 után és négy épület származott az 1900-as évek előtti időből. A legtöbb épületben ( $n=42 ; 66 \%$ ) helyreállítási munkálatokat végeztek az elmúlt öt évben. A fútési rendszert tekintve, szinte az összes épület ( $n=61 ; 95 \%$ ) központi vagy távfútéses radiátorokkal volt felszerelve. Az iskolák 100 méteres körzetében lévő forgalom mértékéről megállapítható, hogy az épületek 17\%-a enyhe, 55\%-a közepes és 28\%-a sűrű forgalmú körzetben helyezkedett el. A kiválasztott osztálytermekről megállapítható, hogy átlagos alapterületük $53 \mathrm{~m}^{2}$ és a felmérés során a tanórák alatt átlagosan 23 tanuló volt jelen. A zsúfoltságot tekintve átlagosan 2,35 $\mathrm{m}^{2}$ jutott egy före. A legmagasabb átlagérték (2,70 m²/fö) a szlovén tantermekben figyelhető meg, míg a legalacsonyabb $(2,11$ $\mathrm{m}^{2} /$ fő) a lengyelországi iskolákban.

Az osztálytermek elhelyezkedését illetően elmondható, hogy a projektben vizsgált tantermek több mint fele ( $n=41,64 \%)$ udvarra vagy kertre néző, a maradék egyharmada ( $n=23,36 \%)$ utcára néző kialakítású volt. Az osztálytermek többségében műanyag padlóburkolat ( $n=26 ; 41 \%)$ vagy parketta ( $n=20 ; 31 \%)$ volt. Azonban az olaszországi általános iskolákban 12 tanteremből tízben a padlót szőnyeg borította. A tantermek számottevő része vagy a földszinten ( $n=29$; 45\%), vagy az első emeleten ( $n=22 ; 34 \%$ ) volt, míg egy tanterem az alagsorban volt kialakítva a magyarországi iskolák közül. Mindösszesen két iskola rendelkezett mechanikus szellőztető rendszerrel. Az osztálytermek 92\%-ában hagyományos krétával ellátott táblát használtak. A takarítási szokásokat nézve, leggyakoribb padlótisztítási módszer a seprés ( $n=34 ; 53 \%)$ vagy a nedves felmosás ( $n=29 ; 45 \%$ ) volt. Látható penészről egy tanteremben számoltak be.

\section{Beltéri levegőminőség a vizsgált általános iskolák osztálytermeiben}

A vizsgálatban részt vevő iskolák beltéri levegőminőségéről készült összesítés az 1. táblázatban található. A 2. táblázatban találhatók a beltéri környezetben vizsgált paraméterek eredményei országos bontásban.

A 3. táblázat mutatja be a beltéri levegőminőséget befolyásoló komponensek országok közötti statisztikai különbségét. Az eredmények rámutatnak arra, hogy a tanulók egyformán vannak-e kitéve a különböző légszennyező anyagoknak, vagy esetleg egyes országok diákjait jelentősebb kitettség éri egyes paraméterek esetén 


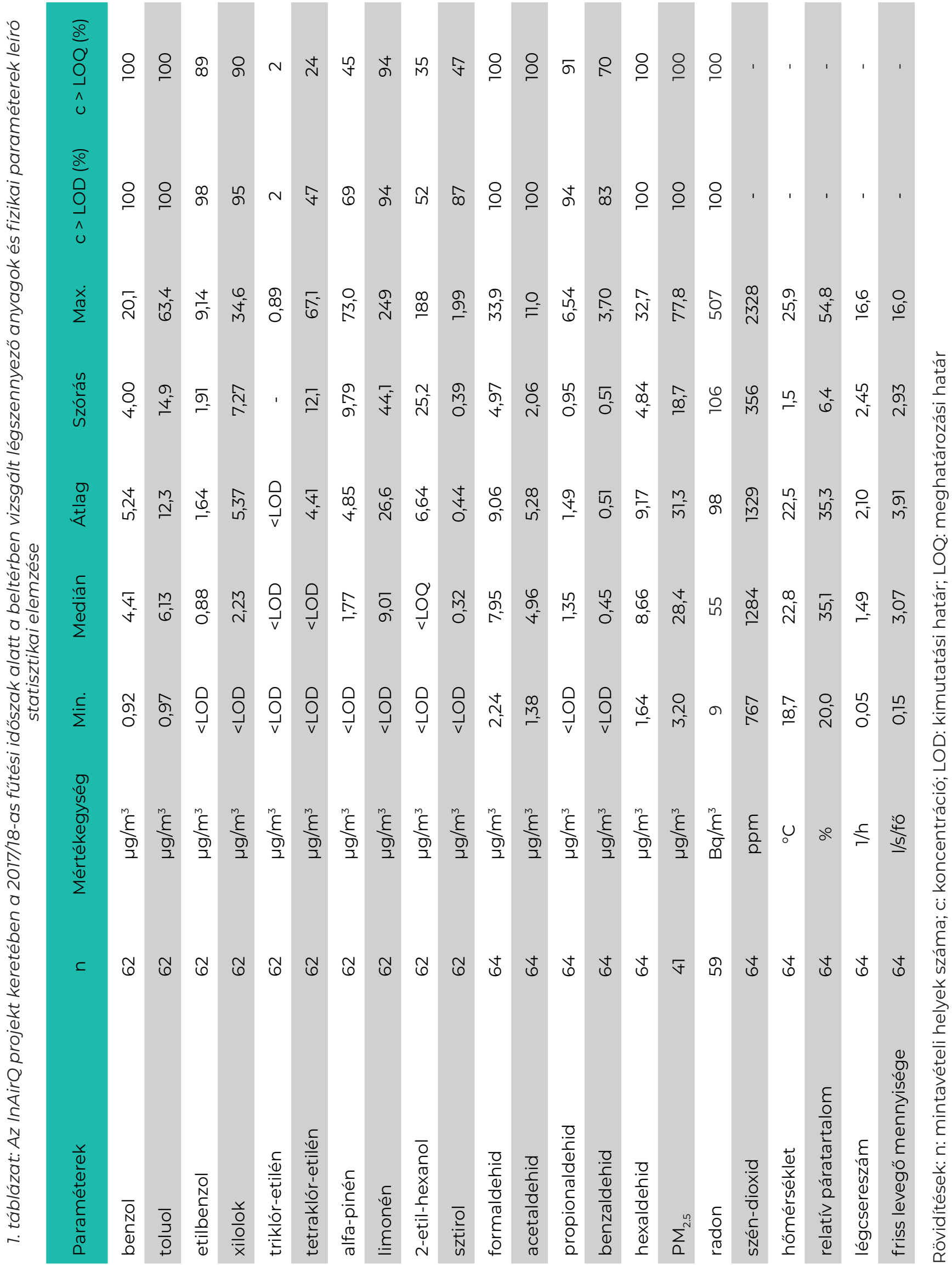




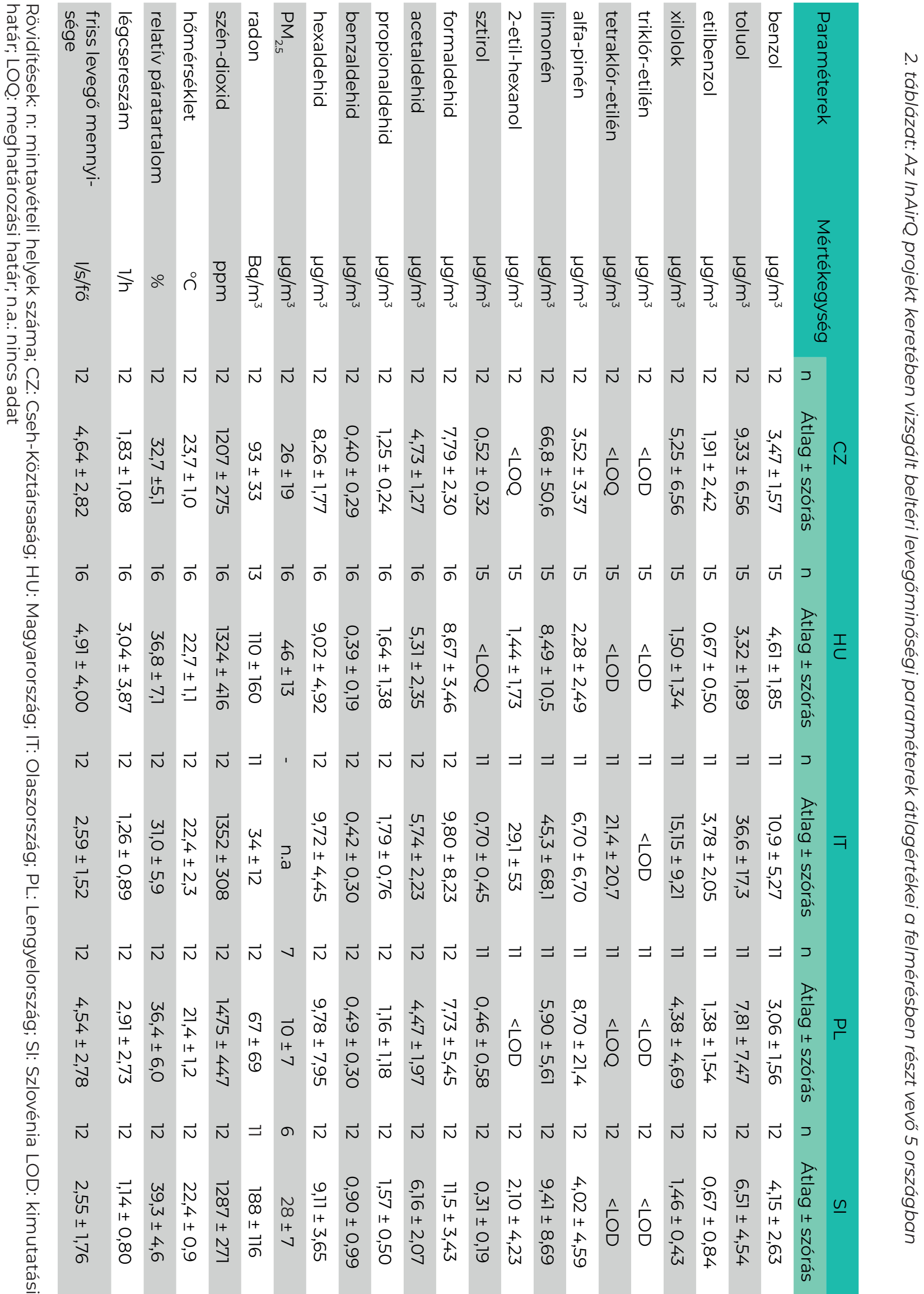


3. táblázat: A beltérben vizsgált levegőminőségi paraméterek területi különbségei az InAirQ projektben részt vevő országok között

\begin{tabular}{|c|c|c|c|c|}
\hline \multirow{2}{*}{ Paraméterek } & \multirow{2}{*}{$n$} & \multicolumn{2}{|c|}{$\begin{array}{l}\text { Kruskal-Wallis próba / } \\
\text { Egyszempontos ANOVA* }\end{array}$} & \multirow{2}{*}{ Mann-Whitney U próba / Kétmintás t-próba* } \\
\hline & & $\mathrm{H} / \mathrm{F}$ & p érték & \\
\hline benzol & 62 & 26,3 & $<0,001$ & IT>PL; IT>CZ; IT>SI; IT>HU; HU>PL \\
\hline toluol & 62 & 33,1 & $<0,001$ & IT>HU; IT>SI; IT>PL; IT>CZ; CZ>HU \\
\hline etilbenzol & 62 & 25,8 & $<0,001$ & $\mathrm{IT}>\mathrm{SI} ; \mathrm{IT}>\mathrm{HU} ; \mathrm{IT}>\mathrm{PL} ; \mathrm{IT}>\mathrm{CZ} ; \mathrm{CZ}>\mathrm{SI} ; \mathrm{CZ}>\mathrm{HU}$ \\
\hline xilolok & 62 & 29,9 & $<0,001$ & IT>SI; IT>HU; IT>PL; IT>CZ; CZ>SI; CZ>HU \\
\hline tetraklór-etilén & 62 & 34,5 & $<0,001$ & IT>PL; IT>CZ; IT>SI; IT>HU; \\
\hline alfa-pinén & 62 & 3,45 & 0,485 & - \\
\hline limonén & 62 & 25,3 & $<0,001$ & $\mathrm{CZ}>\mathrm{PL} ; \mathrm{CZ}>\mathrm{SI} ; \mathrm{CZ}>\mathrm{HU} ; \mathrm{IT}>\mathrm{PL} ; \mathrm{IT}>\mathrm{SI} ; \mathrm{IT}>\mathrm{HU}$ \\
\hline 2-etil-hexanol & 62 & 22,7 & $<0,001$ & $\mathrm{IT}>\mathrm{PL} ; \mathrm{IT}>\mathrm{CZ} ; \mathrm{IT}>\mathrm{SI} ; \mathrm{IT}>\mathrm{HU}$ \\
\hline sztirol & 62 & 12,6 & $<0,05$ & $\mathrm{IT}>\mathrm{SI} ; \mathrm{IT}>\mathrm{HU} ; \mathrm{CZ}>\mathrm{HU}$ \\
\hline formaldehid & 64 & 10,8 & $<0,05$ & $\mathrm{SI}>\mathrm{PL} ; \mathrm{SI}>\mathrm{CZ}$ \\
\hline acetaldehid & 64 & 5,24 & 0,264 & - \\
\hline propionaldehid & 64 & 7,30 & 0,121 & - \\
\hline benzaldehid & 64 & 3,22 & 0,521 & - \\
\hline hexaldehid & 64 & 0,99 & 0,912 & - \\
\hline $\mathrm{PM}_{2.5}$ & 41 & 24,4 & $<0,001$ & $\mathrm{HU}>\mathrm{PL}$; SI>PL; HU>SI; CZ>PL; HU>CZ \\
\hline radon & 59 & 25,9 & $<0,001$ & $\mathrm{SI}>\mathrm{IT} ; \mathrm{CZ}>\mathrm{IT} ; \mathrm{SI}>\mathrm{PL} ; \mathrm{SI}>\mathrm{CZ} ; \mathrm{SI}>\mathrm{HU} ; \mathrm{CZ}>\mathrm{PL}$ \\
\hline szén-dioxid & 64 & 2,46 & 0,652 & - \\
\hline hőmérséklet & 64 & 16,4 & $<0,05$ & $\mathrm{CZ}>\mathrm{PL} ; \mathrm{CZ}>\mathrm{SI}$; $\mathrm{SI}>\mathrm{PL} ; \mathrm{HU}>\mathrm{PL} ; \mathrm{CZ}>\mathrm{HU}$ \\
\hline relatív páratartalom & 64 & 3,82 & $<0,05$ & SI>IT; SI>CZ; HU>IT; PL>IT \\
\hline légcsereszám & 64 & 8,71 & 0,069 & - \\
\hline friss levegő mennyisége & 64 & 7,97 & 0,093 & - \\
\hline
\end{tabular}

*Az esetek többségében a légszennyező komponensek nem mutattak normális eloszlást, kivételt képez a kisméretú aeroszol részecskék $\left(P M_{2.5}\right)$, a hőmérséklet és relatív páratartalom. Mivel a varianciaanalízis további feltételei nem teljesültek a $\mathrm{PM}_{2.5}$ és hőmérséklet esetében, így egyszempontos ANOVA-t és kétmintás t-próbát egyedül a relatív páratartalom esetén alkalmaztunk. A többi esetben Kruskal-Wallis és Mann-Whitney-U statisztikai próbát használtunk a térbeli különbségek feltárására.

Rövidítések: n: mintavételi helyek száma; CZ: Cseh-Köztársaság; F: egyszempontos ANOVA statisztika értéke; H: Kruskal-Wallis próba statisztika értéke; HU: Magyarország; IT: Olaszország; PL: Lengyelország; SI: Szlovénia 
A projekt keretében 10 illékony szerves vegyületet (benzol, etilbenzol, toluol, xilolok, sztirol, tetraklór-etilén, triklór-etilén, limonén, $\alpha$-pinén, 2-etil-hexanol) vizsgáltunk. Az illékony szerves vegyületek közül a legmagasabb beltéri medián koncentráció a limonén és a toluol esetében volt megfigyelhető, míg a benzol, xilolok, $\alpha$-pinén, etilbenzol és sztirol koncentrációk mediánja alacsonyabb volt, mint $5 \mu \mathrm{g} / \mathrm{m}^{3}$ (1. táblázat). A triklór-etilén, a tetraklór-etilén és a 2-etil-hexanol a minták többségében a mennyiségileg biztonságosan meghatározható határ alatt volt. Az illékony szerves vegyületek koncentrációjában jelentős különbségek figyelhetők meg az egyes országok között (3. táblázat). A triklór-etilén esetében a mért koncentráció értékek csak 2\%-a haladta meg a meghatározási határt, ezért a statisztikai elemzésből kizártuk. A 3. táblázatban látható, hogy jelentősen magasabb benzol, toluol, etilbenzol, xilolok, tetraklór-etilén és 2-etilhexanol beltéri koncentráció jellemezte az olaszországi általános iskolák tantermeit, mint a felmérésbe bevont többi ország osztálytermeit. A benzol, toluol, etilbenzol és a xilolok (BTEX) esetében kétszer magasabb átlagkoncentráció figyelhető meg, összehasonlítva az összes vizsgált osztályterem átlagkoncentrációjával. A tetraklór-etilén mennyiségileg meghatározható koncentrációban csak az olaszországi iskolaépületek beltéri levegőjében volt jelen. A tetraklór-etilén olyan oldószer, melyet széles körben használnak textíliák száraz tisztítására. Néhány fogyasztási cikkben is megtalálható, beleértve a festék- és a folteltávolítókat, valamint aeroszolkészítményekben is használják ${ }^{14}$. A 2. táblázatban látható, hogy a 2-etil-hexanol egy nagyságrenddel magasabb koncentrációban volt jelen az olaszországi tantermekben (átlagérték: 29,1 $\mu \mathrm{g} / \mathrm{m}^{3}$ ), összehasonlítva a többi osztályteremmel, ahol az átlagértékek a kimutatási határ és 2,10 $\mu \mathrm{g} / \mathrm{m}^{3}$ között változtak. Ez a vegyület egyes padlóburkoló anyagok és ragasztók hidrolízise során képződhet ${ }^{15}$. Mivel Olaszországban a tantermek többségében ( $n=10)$ a padlót szőnyeg borította, ezáltal ezek nedves tisztítása magas 2 etil-hexanol koncentrációhoz vezethetett. A limonén koncentrációk szignifikánsan magasabbak voltak az olaszországi és a cseh-köztársasági iskolaépületekben a többi ország épületeihez képest. A terpének közül az $\alpha$-pinén medián koncentrációja ötször alacsonyabb volt, mint a limonén koncentrációja. A monoterpének közé tartozó limonén és $\alpha$-pinén vegyületeket illatanyagként használják fogyasztási cikkekben (pl. légfrissítők, tisztítószerek, rovarölő szerek), testápolási termékekben (pl. hajápolási termékek, parfümök), valamit illatos gyertyákban. Számos beltéri tárgyból is származhatnak, főképpen a fa eredetü bútorokból ${ }^{16}$.
A projekt során 5 aldehid (formaldehid, acetaldehid, propionaldehid, benzaldehid, hexaldehid) koncentrációját is vizsgáltuk. Legmagasabb medián értéket a hexaldehid $\left(8,66 \mu \mathrm{g} / \mathrm{m}^{3}\right)$ esetén találtunk, ezt követi csökkenő koncentráció sorrendben a formaldehid (7,95 $\mu \mathrm{g} /$ $\left.\mathrm{m}^{3}\right)$, az acetaldehid $\left(4,96 \mu \mathrm{g} / \mathrm{m}^{3}\right)$, a propionaldehid $(1,35$ $\left.\mu \mathrm{g} / \mathrm{m}^{3}\right)$ és a benzaldehid $\left(0,45 \mu \mathrm{g} / \mathrm{m}^{3}\right)$. Az aldehidek közül a formaldehid koncentrációja mutatott szignifikáns, országok közötti különbséget, a többi vizsgált aldehid koncentrációja minden országban hasonlóan alakult (3. táblázat). A legmagasabb formaldehid koncentráció értékeket a szlovén osztálytermekben mértük (átlagérték: 11,5 $\mu \mathrm{g} / \mathrm{m}^{3}$ ), illetve a legalacsonyabb koncentrációkat a cseh (átlagérték: 7,79 $\mu \mathrm{g} / \mathrm{m}^{3}$ ) és a lengyel tantermekben (átlagérték: 7,73 $\mu \mathrm{g} / \mathrm{m}^{3}$ ). A Francia Környezeti és Munkaegészségügyi Ügynökség (AFSSET) a formaldehidre vonatkozóan $10 \mu \mathrm{g} / \mathrm{m}^{3}$ hoszszú távú beltéri határértéket javasol tüdőfunkciót érintő hosszú távú káros hatások és az élethossznyi többlet rákos halálesetek megelőzése céljából. Ezt a 10 g/ $\mathrm{m}^{3}$ javasolt koncentráció értéket az általunk vizsgált osztálytermek 27\%-a haladta meg. Az aldehideknek számos beltéri forrása van, beleértve bútorokat és fatermékeket, textíliákat, fal- és padlóburkolatokat, festékeket, folyékony tisztító- és fertőtlenítőszereket ${ }^{14}$.

A beltéri $\mathrm{PM}_{2.5}$ tömegkoncentráció értékek 3,20 és $77,8 \mu \mathrm{g} / \mathrm{m}^{3}$ között változtak (7. táblázat). Az összes vizsgált helyszín beltéri $\mathrm{PM}_{2.5}$ tömegkoncentrációját nézve az átlag $31.3 \mu \mathrm{g} / \mathrm{m}^{3}$ volt. Országonként vizsgálva elmondható, hogy a legmagasabb beltéri $\mathrm{PM}_{2.5}$ tömegkoncentráció értékeket a magyar iskolaépületekben mértünk (átlag: $46 \mu \mathrm{g} / \mathrm{m}^{3}$ ), míg Lengyelország osztálytermeit a legkisebb átlag tömegkoncentráció (10 $\mu \mathrm{g} /$ $m^{3}$ ) jellemzi. A WHO éves irányértéke a $P M_{25}$ tömegkoncentrációra vonatkozóan $10 \mu \mathrm{g} / \mathrm{m}^{3}$, melyet az osztálytermekben mért értékek 85,4\%-a ( $n=35)$ meghaladta. A PM ${ }_{2.5}$ tömegkoncentráció vonatkozásában a WHO 24 órás kültéri irányértéke - mely a beltéri környezetek re is alkalmazható - és az EU éves határértéke $25 \mu \mathrm{g} /$ $\mathrm{m}^{3}$, melyet a beltéri $\mathrm{PM}_{2.5}$ tömegkoncentráció értékek 56\%-a ( $n=23)$ lépte át.

A belterekben feldúsuló radon nagyrészt a talajból, kisebb részt az építőanyagból és a levegőből származik. A radon koncentrációja jelentősen eltért az egyes iskolaépületek között és szignifikáns területi különbséget figyeltünk meg az országok között. Az osztálytermekben mért legalacsonyabb $\left(9 \mathrm{~Bq} / \mathrm{m}^{3}\right)$ és legmagasabb $\left(507 \mathrm{~Bq} / \mathrm{m}^{3}\right)$ aktivitáskoncentráció két nagyságrendbeli különbséget mutatott. A Magyarországon található várpalotai iskola kiugró értéke (507 
$\mathrm{Bq} / \mathrm{m}^{3}$ ) adódhat az ottani alapkőzet esetlegesen magasabb radionuklid tartalmából (balatonfelvidéki vörös homokkő), valamint a mintavételezett osztályterem elhelyezkedéséből, ami az alagsorban található. Köztudott, hogy a legmagasabb radonkoncentráció értékek épületen belül az alagsorban figyelhetők meg. A szlovén iskolákat jellemezte a legnagyobb átlagos radon koncentráció $\left(188 \mathrm{~Bq} / \mathrm{m}^{3}\right)$, míg a lengyel tantermeket a legalacsonyabb $\left(34 \mathrm{~Bq} / \mathrm{m}^{3}\right)$.

A szén-dioxid átlagkoncentrációja beltérben 7672328 ppm közötti tartományban változott. Azonban, ahogy a 3. táblázatban látható, szignifikáns országos különbségek nem figyelhetők meg a szén-dioxid koncentráció értékekben. Az egy órára vonatkoztatott legmagasabb átlagkoncentráció értéket (4700 ppm) egy szlovén tanteremben figyeltük meg, azonban az órás maximum a Cseh Köztársaság kivételével a többi országban is meghaladta a 4000 ppm-es órás átlagkoncentrációt. A mért értékek közérthető formába hozásának érdekében Ribéron és mtsai kifejlesztették az ICONE (Indice de CONfinement d'air dans les Ecoles) indexet, melynek segítségével hat különböző kategóriával jellemezhető a levegő elhasználtságának mértéke ${ }^{17}$. Az index a szén-dioxid koncentráció gyakoriságát és intenzitását veszi figyelembe a meghatározott 1000 és 1700 ppm küszöbértékekhez képest. Az ICONE-index kiszámításához felhasználtuk az egy teljes iskolai héten keresztül, az iskolás gyermekek tanórai jelenléte során meghatározott szén-dioxid koncentrációkat. Elöször a szén-dioxid koncentráció értékeket 3 osztályba csoportosítjuk: 1. $\mathrm{n}_{\mathrm{o}}<1000$ ppm alatti szén-dioxid koncentrációk száma a tanterem foglaltsága alatt; 2.1000 ppm < $n_{1}<1700$ ppm; 3. $n_{2}>1700$ ppm. Ezt követően az indexet az 1. egyenlet alkalmazásával számítjuk ki.

$$
\begin{gathered}
\operatorname{ICONE}=\left(\frac{2,5}{\log _{10}(2)}\right) \times \log _{10}\left(1+f_{1}+3 \times f_{2}\right) \\
f_{1}=\left(\frac{n_{1}}{n_{0}+n_{1}+n_{2}}\right) \\
f_{2}=\left(\frac{n_{2}}{n_{0}+n_{1}+n_{2}}\right)
\end{gathered}
$$

ahol:

$f_{\text {f: }} 1000$ és 1700 ppm közötti szén-dioxid koncentráció értékek részaránya,

$\mathrm{f}_{2}$ : 1700 ppm feletti szén-dioxid koncentráció értékek részaránya.

Az index értékekről megállapítható, hogy az osztály- termek $\mathrm{CO}_{2}$ terheltsége 3,1\%-ban extrém, 13\%-ban nagyon magas, 36\%-ban magas, 30\%-ban átlagos, és mindössze 19\%-uk esett az alacsony vagy nem terhelt kategóriába (1. ábra).

A légcsereszám azt fejezi ki, hogy óránként hányszor tud egy helyiségben lévő teljes levegőmennyiség kicserélődni. Egy folyamatos és megfelelő mennyiségü légcsere nagyon fontos a komfortérzet szinten tartására az iskolaépületben tartózkodók számára. A légcsereszám az ASTM E471 szabványnak megfelelően a $\mathrm{CO}_{2}$ koncentráció felhasználásával került meghatározásra18. A módszer alapja, hogy az osztályteremben tartózkodók légzése miatt a zárt tér szén-dioxid koncentrációja növekszik. $\mathrm{A} \mathrm{CO}_{2}$ növekedés mértékét befolyásolja a tanterem geometriája, illetve a benne tartózkodók száma. Mivel a légcsereszám arányos a $\mathrm{CO}_{2}$ koncentráció növekedésével, ezért annak értéke közelíthető különböző számítási módszerekkel. A légcsereszámot a 4. egyenlet felhasználásával számítottuk ki.

$$
A_{B}=6 \times 10^{4} n G_{P}\left\{\Sigma_{t}\left(C_{t}-C_{R}\right)^{-1}\right\} /(V T)-\Delta t^{-1} \ln \left\{\left(C_{1}-C_{R}\right) /\left(C_{0}-C_{R}\right)\right\}
$$

ahol:

$A_{B}$ : légcsereszám (1/h),

n: az osztályteremben tartózkodó személyek száma, $\mathrm{G}_{\mathrm{p}}$ : az egy före jutó átlagos $\mathrm{CO}_{2}$ termelés mértéke (I/ perc $\times$ fö),

$\mathrm{C}_{\mathrm{t}}: \mathrm{CO}_{2}$ koncentráció egy adott időpontban a megfigyelési időablakban (ppm),

$\mathrm{C}_{\mathrm{R}}$ : $\mathrm{CO}_{2}$ koncentráció a kültéri levegöben (ppm),

V: az osztályterem térfogata $\left(\mathrm{m}^{3}\right)$,

$\mathrm{T}: \mathrm{CO}_{2}$ koncentráció mérés adatainak száma a megfigyelési időablakban,

$C_{0}$ és $C_{1}$ : a megfigyelési időablak kezdetén és végén mért $\mathrm{CO}_{2}$ koncentráció (ppm),

$\Delta \mathrm{t}$ : a $C_{0}$ és $C_{1}$ mérések közötti időszak (h).

Az egy före jutó friss levegő mennyiség meghatározása a tanterem térfogatának, az ott tartózkodó diákok számának, illetve a légcsereszám figyelembevételével történt. Az eredményeket a 1. és 2. táblázat foglalja öszsze. Mind a légcsereszám, mind az egy főre jutó friss levegő mennyisége a vizsgált tantermekben jelentősen változott, azonban szignifikáns különbségeket nem azonosítottunk az országok között (3. táblázat). Az epidemiológiai tanulmányok áttekintése alapján a friss levegő szükséglet mennyiségét 4 l/másodpercben határozták meg személyenként ${ }^{19}$. Az általunk vizsgált tantermek 64\%-át jellemezte alacsonyabb friss levegő utánpótlás. Spearman-rangkorrelációval vizsgáltuk a 
szellőztetési paraméterek és a beltéri légszennyezők közötti kapcsolatot. A tipikus beltéri forrásokkal (formaldehid, acetaldehid, hexaldehid) rendelkező vegyületek koncentrációja negatívan korrelált a szellőztetéssel kapcsolatos paraméterekkel (4. táblázat).

A komfortérzetünkre nem csak a belső terek széndioxid koncentrációja van hatással, hanem annak hőmérséklete, relatív páratartalma is. Az átlagos hőmérséklet értékek beltérben 18,7 - 25,9 ${ }^{\circ} \mathrm{C}$, kültéren -11,2 - 16,9 ${ }^{\circ} \mathrm{C}$ közötti tartományban, míg az átlagos relatív páratartalom értékek beltérben 20,0 - 54,8\%, kültéren 29,7 - 90,9\% közötti tartományban mozogtak. A legmagasabb relatív páratartalom értékek Szlovéniában, míg a legalacsonyabbak Olaszországban figyelhetőek meg. A szén-dioxiddal ellentétben a hőmérséklet és a relatív páratartalom szignifikáns országos különbséget mutatott (3. táblázat).

\section{A bel- és kültéri levegőminőség közötti kapcsolat}

A vizsgálatban részt vevő iskolák kültéri levegőminőségéről készült összesítés az 5. táblázatban található. A 6 . táblázatban találhatók a kültéri környezetben vizsgált paraméterek eredményei országos bontásban.

A bel- és kültéren mért koncentrációk aránya (indoor/outdoor, I/O) elterjedten alkalmazott módszer annak eldöntésére, hogy egy adott légszennyezó komponens esetében a beltéri vagy a kültéri források jelentősebbek-e. A medián I/O arányokat a 7. táblázat tartalmazza. Mivel néhány célkomponens mediánja mennyiségileg nem volt meghatározható, ezért a torzítás elkerülése érdekében az azokra vonatkozó arányok meghatározását elvetettük.

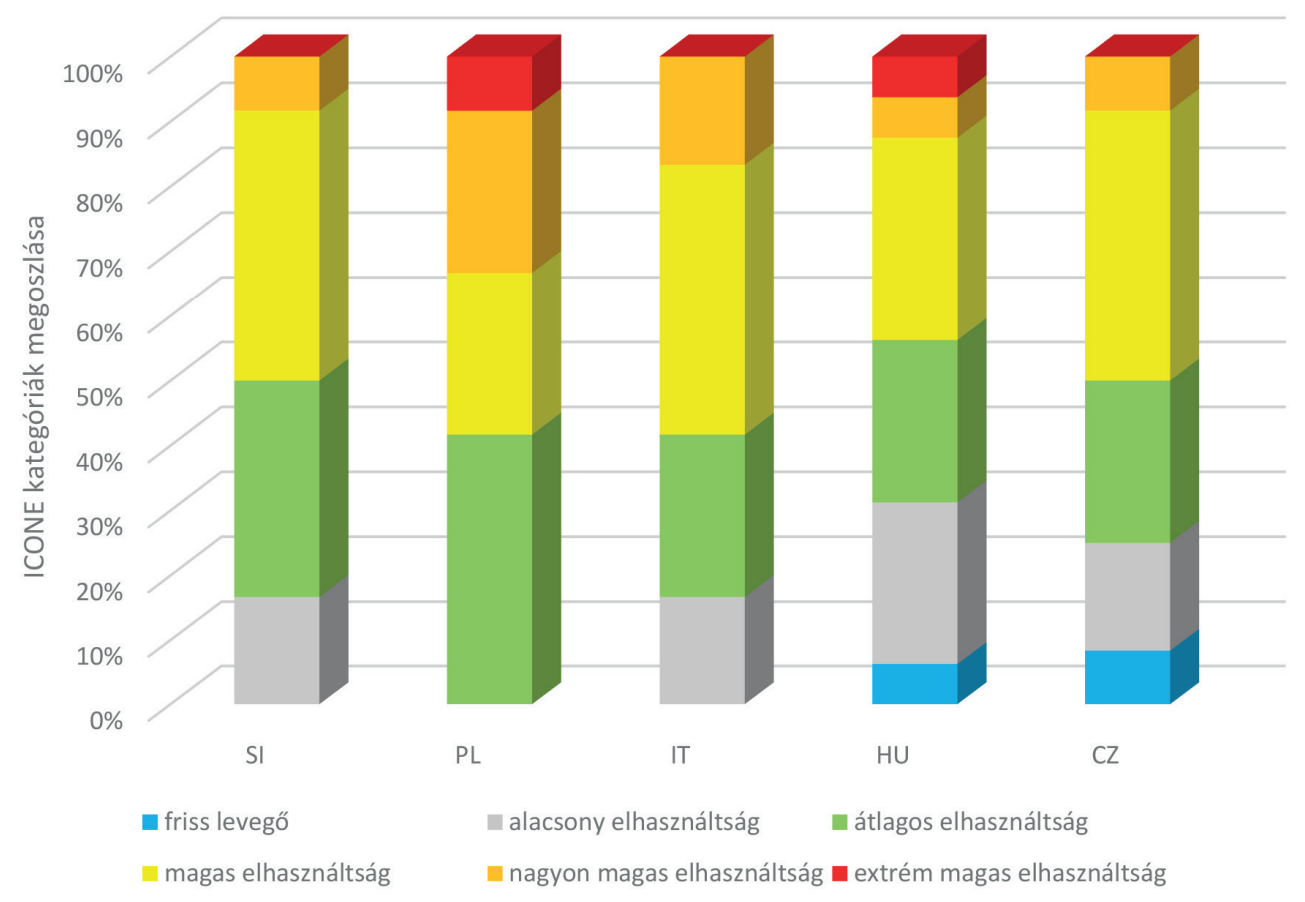

7. ábra: Az ICONE kategóriák megoszlása országonként a vizsgált iskolaépületek között 


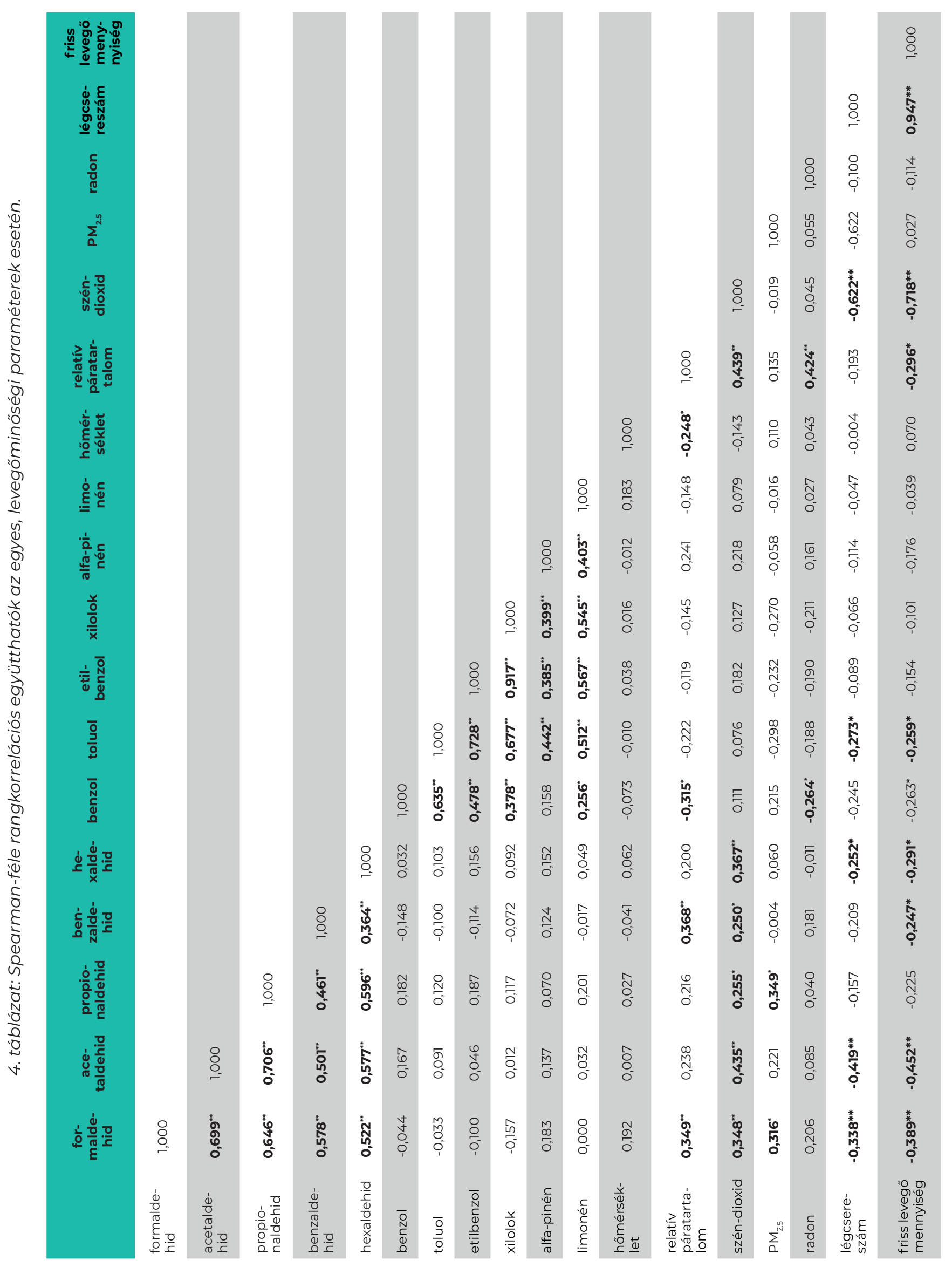




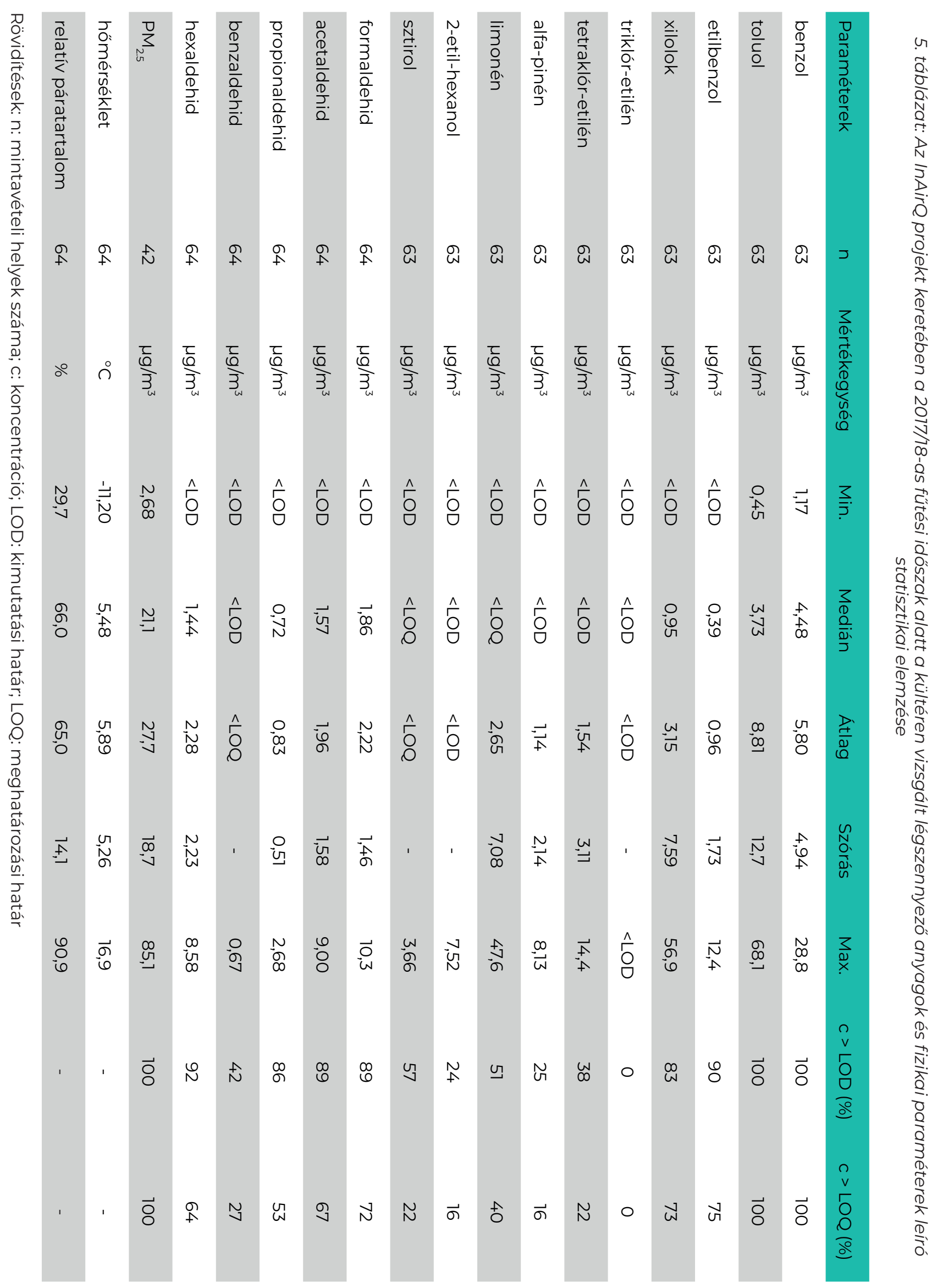




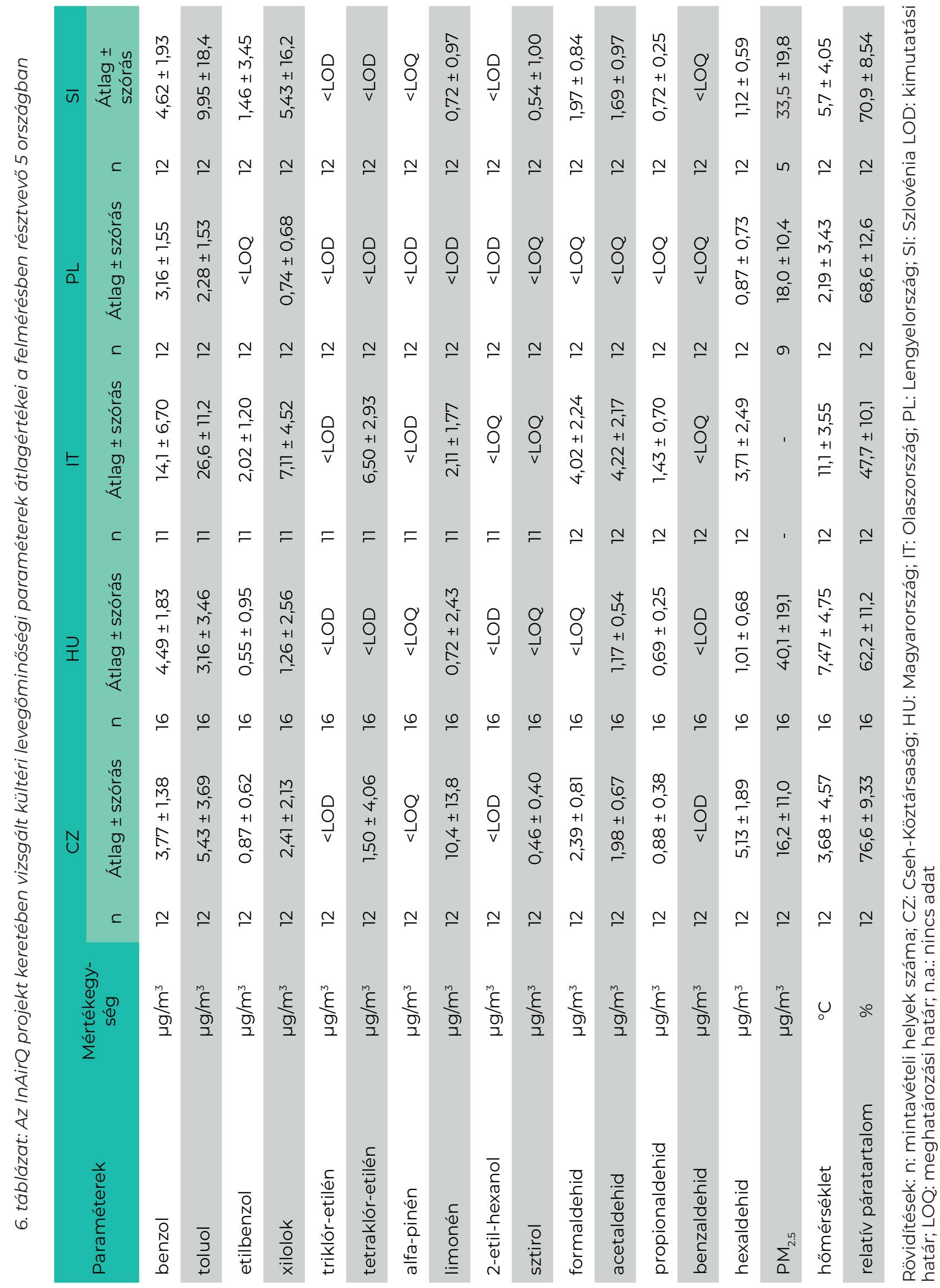


7. táblázat: A légszennyezők bel - és kültéri medián koncentrációinak aránya, valamint az egyes légszennyezök bel- és kültéri koncentráció értékeinek kapcsolata

\begin{tabular}{|c|c|c|c|c|c|c|c|c|c|}
\hline \multirow{2}{*}{ Paraméterek } & \multicolumn{6}{|c|}{ medián beltér/kültér koncentráció arány } & \multirow[b]{2}{*}{$r_{s}$} & \multirow{2}{*}{ p-érték } & \multirow{2}{*}{$n$} \\
\hline & Összes & $C Z$ & $\mathrm{HU}$ & IT & PL & SI & & & \\
\hline benzol & 0,93 & 0,95 & 0,96 & 0,84 & 0,86 & 0,93 & 0,849 & $<0,001$ & 61 \\
\hline toluol & 1,46 & 1,75 & 1,46 & 1,20 & 2,17 & 1,08 & 0,707 & $<0,001$ & 61 \\
\hline etilbenzol & 2,01 & 2,07 & 2,00 & 1,87 & 4,19 & 1,58 & 0,560 & $<0,001$ & 61 \\
\hline xilolok & 1,99 & 2,13 & 1,99 & 2,30 & 3,37 & 1,59 & 0,644 & $<0,001$ & 61 \\
\hline alfa-pinén & 2,38 & 2,33 & 2,11 & 10,4 & 4,31 & 1,03 & 0,246 & $>0,05$ & 61 \\
\hline limonén & 23,2 & 6,11 & 28,9 & 21,9 & 31,3 & 12,2 & 0,406 & $<0,05$ & 61 \\
\hline formaldehid & 4,31 & 3,26 & 6,02 & 2,09 & 5,27 & 6,67 & 0,095 & $>0,05$ & 64 \\
\hline acetaldehid & 7,86 & 4,73 & 9,86 & 4,25 & 9,59 & 9,28 & 0,066 & $>0,05$ & 64 \\
\hline propionaldehid & 1,62 & 1,40 & 2,07 & 1,39 & 1,49 & 2,39 & 0,399 & $<0,05$ & 64 \\
\hline hexaldehid & 6,18 & 1,48 & 8,87 & 2,82 & 9,88 & 8,68 & 0,275 & $<0,05$ & 64 \\
\hline $\mathrm{PM}_{2.5}$ & 1,07 & 1,34 & 1,13 & n.a & 0,76 & 1,05 & 0,507 & $<0,001$ & 39 \\
\hline
\end{tabular}

Rövidítések: CZ: Cseh-Köztársaság; HU: Magyarország; IT: Olaszország; PL: Lengyelország; SI: Szlovénia; rs: Spearman-féle rangkorrelációs együttható; n: mintavételi helyek száma

Annak ellenére, hogy a BTEX vegyületek szignifikánsan magasabbak voltak az olaszországi osztálytermekben, Lengyelország kivételével minden országban hasonló I/O koncentráció arányokat tapasztaltunk. A 7. táblázatban szintén látható a Spearman-féle rangkorreláció eredménye, mely a BTEX vegyületek esetén erősen szignifikáns és pozitív kapcsolatot mutat a beltéri és kültéri értékek között. Marzocca és mtsai (2017) öt kategóriába sorolták a légszennyezőket a beltér/kültér arányok alapján ( $/ / O>5 ; 2<1 / O<5 ; 0,5<1 / O<2 ; 0,2<1 / O<0,5$; $\mathrm{I} / O<0.2)$, melyeknél az I. kategóriát (I/O >5), mint a nagyon magas és az $\mathrm{V}$. kategóriát $(\mathrm{I} / \mathrm{O}<0.2)$, mint nagyon alacsony beltéri forrással rendelkező kategóriákat érdemes kiemelni20. Az összesített medián arányokat nézve, az illékony szerves vegyületek közül a limonénnek az I/O koncentráció aránya $(23,2)$ az I. kategóriába (1/O>5), míg az etilbenzolnak (2,01) és az $\alpha$-pinénnek $(2,38)$ a II. kategóriába esett. A többi illékony szerves vegyület (toluol, xilolok) a III. $(0,5<1 / O<2)$ kategóriába sorolható. Így kijelenthető, hogy ezen komponensek a vizsgálatba bevont osztálytermekben bizonyosan beltéri forrásokból (pl. oldószerek, bevonatok, szintetikus illatanyagok, ragasztók, festékek és tisztítószerek) is származnak. Továbbá a BTEX vegyületek I/O arányairól elmondható, hogy a legkisebb medián érték a benzol $(0,93)$ esetén figyelhető meg. A benzol tekintetében a I/O arány egyhez közeli, így kijelenthető, hogy nem rendelkezik jelentős beltéri forrással. A benzol fő forrása a közúti közlekedésnek tulajdonítható. Az Európai Bizottság az éves kültéri benzol koncentrációra 5 mg/ $\mathrm{m}^{3}$ koncentráció értéket határozott meg határértékként. Ezt a szintet a vizsgált osztálytermek 37\%-ában meghaladta a benzol koncentrációja, míg a többi iskolában alacsonyabb koncentráció értékeket mértünk. Azonban a benzol tekintetében a WHO nem ad meg biztonságos irányértéket, mivel a legkisebb koncentrációban is egészségkárosító hatású. Ahogy fentebb említettük, a limonénhez tartozott a legmagasabb I/O medián koncentráció arány $(23,2)$, mely jelzi, hogy elsősorban beltéri forrással rendelkezik.

Látható, hogy az acetaldehid $(7,86)$, a hexaldehid $(6,18)$, valamint a formaldehid $(4,31)$ értékek nagyon magas - magas (I. és II. kategória) I/O aránnyal rendelkeznek. Ebből adódóan megállapítható, hogy a magas aldehid koncentrációk az osztálytermekben beltéri forrásokból erednek és dúsulnak fel a beltéri környe- 
zetben. A vizsgált aldehidek közül a bel- és a kültéri koncentráció értékek csak a propionaldehid és a hexaldehid esetében korreláltak szignifikánsan (7. táblázat).

A kültéri $\mathrm{PM}_{2.5}$ tömegkoncentráció értékek 2,68 és $85,1 \mu \mathrm{g} / \mathrm{m}^{3}$ között változtak, átlaguk $27,3 \mu \mathrm{g} / \mathrm{m}^{3}$ volt (5 táblázat). Országos átlagokat tekintve, a legmagasabb kültéri $\mathrm{PM}_{2.5}$ tömegkoncentráció értékek a magyar iskolaépületek környezetében voltak megfigyelhetők (átlag: 40,1 $\mu \mathrm{g} / \mathrm{m}^{3}$ ), míg a Cseh-Köztársaságot a legalacsonyabb átlagkoncentráció $\left(16,2 \mu \mathrm{g} / \mathrm{m}^{3}\right)$ jellemezte (6. táblázat). Az I/O arányokat nézve, a lengyel iskolaépületek kivételével a $P M_{2.5}$ tömegkoncentráció értékei valamivel magasabbak voltak beltérben, mint a kültéri értékek. A medián I/O arány 0,76 és 1,34 között változott az öt közép-európai országban. Az I/O arányok 80\%-a alacsonyabb volt, mint kettő, mely azt jelzi, hogy a beltéri források kisebb mértékben járulnak hozzá a $P M_{2.5}$ tömegkoncentrációhoz, és megerősítik azt a tényt, hogy a finom részecskék nagyrészt kültéri eredetúek ${ }^{21}$. A bel- és a kültéri $P_{2.5}$ tömegkoncentráció értékek között meghatározott szignifikáns, pozitív összefüggés sem mond ellent a korábbi tanulmányoknak (7. táblázat).

\section{Az InAirQ projekt eredményeinek összehasonlítása különbözö nemzetközi tanulmányokkal}

Az InAirQ projekt eredményeit összehasonlítottuk az általános iskolák beltéri levegőminőségének felmérésére irányuló, az elmúlt két évtizedben végzett nemzetközi tanulmányok (SINPHONIE', SEARCH7 ${ }^{7}$ AIRMEX ${ }^{22}$ és $\mathrm{HESE}^{3}$ ) eredményeivel (8. táblázat). A táblázatban látható, hogy a formaldehid átlagkoncentrációja minden esetben alacsonyabbnak bizonyult a korábbi vizsgálatokkal szemben. Azonban az alacsonyabb koncentráció nem feltétlen eredményezi azt, hogy ezen komponens mennyisége csökkent az idők folyamán. A különbség egyrészt adódhat abból, hogy különböző mintavételi stratégiát alkalmaztak (pl: a SINPHONIE felmérés során a mintavételt nem csak kizárólag a tanítási időben végezték), másrészt a tantermekben lévő forrásösszetétel is eltérhet. A tanulmányokban mért formaldehid koncentrációértékek az AFSSET által javasolt (10 $\mu \mathrm{g} /$ $m^{3}$ ) koncentráció értéket esetenként túllépték, azonban egyik felmérésnél sem haladták meg a WHO által javasolt $\left(100 \mu \mathrm{g} / \mathrm{m}^{3}\right)$ szintet. A további aldehideket tekintve, korlátozott számú adat állt rendelkezésre, mivel a felmérések közül egyedül az AIRMEX tanulmányban vizsgálták az általunk is meghatározott vegyületeket.
Az eredmények azt mutatják, hogy az AIRMEX projektben mért koncentrációk minden esetben meghaladták a jelen tanulmányban kimutatott értékeket.

A benzol eredmények összehasonlításával elmondható, hogy az InAirQ projekt által mért átlagkoncentrációk megegyeznek a korábban végzett felmérések eredményeivel. Az összehasonlítás nem mutatott egyértelmú időbeli tendenciát. Mivel a beltérben jelenlévő benzol főként kültéri eredetű, ennek okán a projektek nagy hangsúlyt fektettek az iskolaépületek reprezentatív kiválasztására. Így egységesen vizsgáltak forgalmas úthoz közeli, illetve a forgalomtól távol elhelyezkedő iskolaépületeket. Feltételezhetően a benzol-koncentrációk ezért nem mutatnak nagy, időbeli változást. Benzol esetén egyedül az InAirQ projekt keretén belül mértek az Európai Bizottság által meghatározott, kültéri környezetre vonatkozó éves határérték (5 $\mu \mathrm{g} / \mathrm{m}^{3}$ ) feletti értéket. Jelentős eltéréseket nem tapasztaltunk a toluol, az etilbenzol és a xilol vegyületek esetén, melyek közel megegyeztek az AIRMEX és SEARCH felmérésekben résztvevő iskolákban mért koncentrációértékekkel.

A triklór-etilén és a tetraklór-etilén, a WHO által is kiemelt jelentőségü vegyületek az egészségre gyakorolt daganatkeltő hatásuk miatt. Az InAirQ és a SINPHONIE projektben a vizsgált osztálytermek többségében nem voltak jelen kimutatható koncentrációban. Az eredmények azt mutatták, hogy manapság a triklór-etilén nem tartozik az elsődleges légszennyező anyagok közé az iskolai környezetben, míg a tetraklór-etilén magas koncentrációban csak elvétve fordult elő.

Az InAirQ projekt iskolaépületeiben a beltéri limonén koncentráció értékek, a SINPHONIE projekt iskolái körében mért értékekkel egyeznek meg. Azonban kiugró beltéri limonén koncentráció is megfigyelhető a SINPHONIE felmérés keretein belül. Azokat az iskolákat, amelyeket az AIRMEX tanulmány során vizsgáltak, alacsonyabb limonén koncentráció jellemzett.

A radon koncentrációja kisebb eltérést mutatott az egyes épületek között az InAirQ vizsgálatban a SINPHONIE felméréshez képest. Utóbbi esetén a maximum érték egy nagyságrenddel magasabb volt az általunk mértnél.

Az InAirQ projektben részt vevő 5 ország viszonylatában alacsonyabb beltéri $\mathrm{PM}_{2.5}$ tömegkoncentráció értéket mértünk jelen projektben, mint a SINPHONIE felmérésben. Megjegyezzük, hogy a SINPHONIE projektben a közép-kelet-európai országokra vonatkozóan magasabb kültéri $\mathrm{PM}_{2.5}$ tömegkoncentráció értékeket mértek, mint az InAirQ projektben, mely egyéb 
tényezők mellett magasabb beltéri tömegkoncentráció értéket eredményezhetett.

A szén-dioxid koncentrációt tekintve a jelen felmérés általános iskoláit hasonló értékek jellemezték, mint a korábbi vizsgálatok során felmért épületeket. Annak ellenére, hogy egy sokat hangoztatott problémáról van szó és rengeteg szemléletformálási kampány valósult meg az elmúlt években, a beltéri szén-dioxid koncentráció alakulásában nem figyelhető meg jelentős javulás. Ez azt mutatja, hogy a tantermek szellőztetésével kapcsolatos kampányok nem voltak sikeresek, vagy az épületek energetikai felújítása, szigetelése miatt csökkent a légcsere mértéke. Érdemes megjegyezni, hogy a mechanikus szellőztető rendszerrel felszerelt iskolaépületek aránya továbbra is alacsony a természetes szellőztetésű iskolaépületek számához képest Közép-Európában. Mivel a legtöbb vizsgált iskola tervezése a természetes szellőzés elve mentén történt, a tanítási idő alatt gyakoribb szellőztetésre van szükség.

A komfortérzetünkre hatással lehet a hőmérséklet és a páratartalom. Ezek a paraméterek nem feltétlen egészségkárosító hatásúak, viszont közvetetten hatással lehetnek egészségünkre. A komfortérzetet befolyásoló paraméterek közül a relatív páratartalom alacsonyabb volt az InAirQ vizsgálatban a SINPHONIE tanulmányhoz képest, azonban az utóbbi vizsgálatban extrém értékeket is megfigyeltek mind az alacsony, mind a magas tartományokban.

8. táblázat: Az InAirQ tanulmány keretében vizsgált levegőminőségi paraméterek eredményeinek összehasonlítása a korábbi nemzetközi tanulmányok eredményeivel

\begin{tabular}{|c|c|c|c|c|c|c|c|}
\hline Paraméterek & $\begin{array}{l}\text { Mérté- } \\
\text { kegység }\end{array}$ & Tanulmány* & $\begin{array}{l}\text { Mintavételi } \\
\text { periódus** }\end{array}$ & Átlag & Szórás & Medián & Tartomány*** \\
\hline \multirow[t]{4}{*}{ benzol } & $\mu \mathrm{g} / \mathrm{m}^{3}$ & InAirQ & $2017-2018$ & 5,2 & 4,0 & 4,4 & $0,9-20,1^{a}$ \\
\hline & & SINPHONIE & $2010-2012$ & 4 & 6 & 2 & $<\mathrm{LOD}-38^{a}$ \\
\hline & & SEARCH & $2006-2013$ & 4,3 & $\mathrm{n}, \mathrm{a}$ & $\mathrm{n}, \mathrm{a}$ & $1,95-7,4^{b}$ \\
\hline & & AIRMEX & $2003-2008$ & 3,8 & 4,5 & 2,6 & $0,6-31^{a}$ \\
\hline \multirow[t]{3}{*}{ toluol } & $\mu \mathrm{g} / \mathrm{m}^{3}$ & InAirQ & 2017 - 2018 & 12,3 & 14,9 & 6,1 & $0,97-63,4^{a}$ \\
\hline & & SEARCH & $2006-2013$ & 15,1 & $\mathrm{n}, \mathrm{a}$ & $\mathrm{n}, \mathrm{a}$ & $4,6-29,5^{b}$ \\
\hline & & AIRMEX & $2003-2008$ & 12,5 & 13,4 & 7,9 & $1-52^{a}$ \\
\hline \multirow[t]{3}{*}{ etilbenzol } & $\mu \mathrm{g} / \mathrm{m}^{3}$ & InAirQ & $2017-2018$ & 1,6 & 1,9 & 0,9 & $<$ LOD $-9,14^{a}$ \\
\hline & & SEARCH & $2006-2013$ & 1,4 & $\mathrm{n}, \mathrm{a}$ & $\mathrm{n}, \mathrm{a}$ & $0,8-1,82^{b}$ \\
\hline & & AIRMEX & $2003-2008$ & 2,6 & 3,6 & 1,5 & $<$ LOD $-22,5^{a}$ \\
\hline \multirow[t]{3}{*}{ xilolok } & $\mu \mathrm{g} / \mathrm{m}^{3}$ & InAirQ & $2017-2018$ & 5,4 & 7,3 & 2,2 & $<$ LOD $-34,6^{a}$ \\
\hline & & SEARCH & $2006-2013$ & 6,6 & $\mathrm{n}, \mathrm{a}$ & $\mathrm{n}, \mathrm{a}$ & $4,3-9,1^{b}$ \\
\hline & & AIRMEX & $2003-2008$ & 8,7 & 13,8 & 4,7 & $1,3-97,3^{a}$ \\
\hline \multirow[t]{2}{*}{ triklór-etilén } & $\mu \mathrm{g} / \mathrm{m}^{3}$ & InAirQ & $2017-2018$ & $<\mathrm{LOD}$ & 0,13 & $<$ LOD & $<$ LOD - 0,9a \\
\hline & & SINPHONIE & $2010-2012$ & 3 & 8 & $<$ LOD & $<$ LOD - $126^{a}$ \\
\hline \multirow[t]{2}{*}{ tetraklór-etilén } & $\mathrm{\mu g} / \mathrm{m}^{3}$ & InAirQ & 2017 - 2018 & 4,4 & 12,1 & $<\mathrm{LOD}$ & $<$ LOD $-67,1^{a}$ \\
\hline & & SINPHONIE & 2010 - 2012 & 1 & 2 & $<$ LOD & $<$ LOD - $81^{a}$ \\
\hline \multirow[t]{2}{*}{ alfa-pinén } & $\mu \mathrm{g} / \mathrm{m}^{3}$ & InAirQ & 2017 - 2018 & 4,9 & 9,8 & 1,8 & $<$ LOD - 73a \\
\hline & & AIRMEX & $2003-2008$ & 2,3 & 2,8 & 1,7 & $<$ LOD $-16,2^{a}$ \\
\hline
\end{tabular}




\begin{tabular}{|c|c|c|c|c|c|c|c|}
\hline \multirow[t]{3}{*}{ limonén } & $\mu \mathrm{g} / \mathrm{m}^{3}$ & InAirQ & $2017-2018$ & 26,6 & 44,1 & 9 & $<$ LOD - 259a \\
\hline & & SINPHONIE & $2010-2012$ & 38 & 133 & 9 & $<$ LOD $-672^{a}$ \\
\hline & & AIRMEX & $2003-2008$ & 9,2 & 11,5 & 2,7 & $<L O D-45,9^{a}$ \\
\hline \multirow[t]{4}{*}{ formaldehid } & $\mu \mathrm{g} / \mathrm{m}^{3}$ & InAirQ & $2017-2018$ & 9,1 & 5,0 & 8,0 & $2,2-33,9^{a}$ \\
\hline & & SINPHONIE & $2010-2012$ & 15 & 11 & 12 & $1,0-66^{a}$ \\
\hline & & SEARCH & $2006-2013$ & 10,1 & $\mathrm{n}, \mathrm{a}$ & $\mathrm{n}, \mathrm{a}$ & $1,7-33,1^{\mathrm{b}}$ \\
\hline & & AIRMEX & $2003-2008$ & 17,5 & 10 & 14,6 & $8,2-49,7^{a}$ \\
\hline \multirow[t]{2}{*}{ acetaldehid } & $\mu \mathrm{g} / \mathrm{m}^{3}$ & InAirQ & $2017-2018$ & 5,3 & 2 & 5 & $1,4-11^{a}$ \\
\hline & & AIRMEX & $2003-2008$ & 8,2 & 4,7 & 7,5 & $3,5-21,7^{a}$ \\
\hline \multirow{2}{*}{$\begin{array}{l}\text { propionalde- } \\
\text { hid }\end{array}$} & $\mu \mathrm{g} / \mathrm{m}^{3}$ & InAirQ & $2017-2018$ & 1,5 & 1 & 1,4 & $<\mathrm{LOD}-6,5^{a}$ \\
\hline & & AIRMEX & $2003-2008$ & 2,7 & 2,6 & 2,3 & $1-15,9^{a}$ \\
\hline \multirow[t]{2}{*}{ hexaldehid } & $\mu \mathrm{g} / \mathrm{m}^{3}$ & InAirQ & $2017-2018$ & 9,2 & 4,8 & 8,7 & $1,6-32,7^{a}$ \\
\hline & & AIRMEX & $2003-2008$ & 17,8 & 11 & 15,4 & $7,6-47^{a}$ \\
\hline \multirow[t]{2}{*}{ radon } & $\mu \mathrm{g} / \mathrm{m}^{3}$ & InAirQ & $2017-2018$ & 98 & 106 & 55 & $9-507^{a}$ \\
\hline & & SINPHONIE & $2010-2012$ & 205 & 2146 & 101 & $<$ LOD - $9190^{a}$ \\
\hline \multirow[t]{2}{*}{$\mathrm{PM}_{2.5}$} & $\mu \mathrm{g} / \mathrm{m}^{3}$ & InAirQ & $2017-2018$ & 31 & 19 & 28 & $3-78^{a}$ \\
\hline & & SINPHONIE & 2010 - 2012 & 44 & 37 & 37 & $4-250^{a}$ \\
\hline \multirow[t]{3}{*}{ szén-dioxid } & ppm & InAirQ & $2017-2018$ & 1329 & 356 & 1284 & $767-2328^{a}$ \\
\hline & & SINPHONIE & $2010-2012$ & 1433 & 856 & 1257 & $269-4960^{a}$ \\
\hline & & HESE & $2004-2005$ & 1467 & 683 & 1490 & $525-3475^{a}$ \\
\hline \multirow[t]{3}{*}{ hőmérséklet } & ${ }^{\circ} \mathrm{C}$ & InAirQ & $2017-2018$ & 22,5 & 1,5 & 22,8 & 18,7 - 25,9a \\
\hline & & SINPHONIE & 2010 - 2012 & 20 & 2 & 21 & $-8-30 a$ \\
\hline & & HESE & $2004-2005$ & 23,3 & 2 & 22,7 & $20,5-29,5^{a}$ \\
\hline \multirow{2}{*}{$\begin{array}{l}\text { relatív páratar- } \\
\text { talom }\end{array}$} & $\%$ & InAirQ & $2017-2018$ & 35 & 6 & 35 & $20-55^{a}$ \\
\hline & & SINPHONIE & 2010 - 2012 & 43 & 12 & 42 & $6-98^{a}$ \\
\hline \multirow[t]{2}{*}{ légcsereszám } & $1 / h$ & InAirQ & $2017-2018$ & 2,10 & 2,45 & 1,49 & $0,05-16,6^{a}$ \\
\hline & & SINPHONIE & 2010 - 2012 & 1 & 1 & 0 & $0-4^{a}$ \\
\hline
\end{tabular}

Rövidítések: LOD: kimutatási határ; n.a.: nincs adat

* A vizsgált iskolaépületek és osztálytermek száma az egyes projektekben: SINPHONIE: 114 iskolaépület, 342 tanterem $^{8}$; SEARCH: 100 iskolaépület, 388 tanterem; AIRMEX: nem áll rendelkezésre adat22; HESE: 21 iskolaépület, 46 osztályterem³.

** A mintavétel által lefedett időszakok: SINPHONIE: fütés és nem fütés időszakok; SEARCH: fütési időszak; AIRMEX: fütési és nem fütési időszakok; HESE: fütési időszak

*** a: minimum és maximum koncentrációs értékek a teljes adathalmazra; b: minimum és maximum koncentrációs értékek az országos átlagkoncentrációt tekintve. 


\section{Összefoglalás}

A beltéri levegő minőségének vizsgálata és a levegőminőség javítását célzó intézkedések meghozatala kulcsfontosságú az iskolás gyermekek egészségének megőrzésében. Egyre több tanulmány mutat rá a korábban már azonosított, illetve az újonnan felmerülő, beltéri környezettel kapcsolatos problémákra. Az InAirQ projekt új adatokat szolgáltat a beltéri levegőminőséggel kapcsolatban 5 közép-európai ország 64 általános iskolájának épületében végzett felmérések alapján. Számos beltéri légszennyező anyag koncentrációjában jelentős területi eltéréseket azonosítottunk. Általánosságban elmondható, hogy a vizsgált épületekben gyakoriak és hasonlóak voltak a beltéri levegőminőséggel kapcsolatos problémák. A mérési eredmények alapján a szellőztetésre továbbra sem fektetnek elegendő hangsúlyt.

\section{Köszönetnyilvánítás}

Az InAirQ projektet (Transnational Adaption Actions for Integrated Indoor Air Quality Management) az Interreg CENTRAL EUROPE program finanszírozta.

A mintavételben és a mérésekben szeretnénk köszönetünket kifejezni az alábbi személyeknek: Boglárka Balogh Sára (NNK), Homoki Zsolt (NNK), Agnieszka Kapsa (NIOM). A szerzők köszönetüket fejezik ki a felmérésben részt vevő iskolák vezetőségének, a pedagógusoknak és természetesen a gyermekeknek és szüleiknek, gondviselőiknek is.

\section{Szerzők hozzájárulása}

Sz. T. tervezte és koordinálta a vizsgálatot; Sz. M., Cs. Zs., B. K., H. K., A. K., A. J., A. K., P. O., A. D., A. D. M., and S. F koordinálta és kivitelezte a mintavételi kampányt; Sz. M. és Cs. Zs. végezte a kémiai elemzéseket; Sz. M. az adatelemzést végezte; Sz. M. és Sz. T elkészítette a kéziratot.

\section{Érdekeltségek}

A szerzőknek nincsenek a tartalmat érintő érdekeltségeik.

\section{Nyilatkozatok}

A szerzők nyilatkoznak arról, hogy a cikk végleges változatát (külföldi társszerzők esetén az angol nyelvü összefoglalót) valamennyi szerző elolvasta és jóváhagyta.

\section{Irodalomjegyzék}

1. Szabó E., Varró M. J., Mácsik A., Rudnai P., Vaskövi É. 2008: Gyermekek körében jelentkező légúti és allergiás tünetek gyakoriságának és kockázati tényezőinek vizsgálata három városban. Egészségtudomány. LII.4. p. 1-40.

2. Kephalopoulos S., Csobod É., De Bruin Y. B., De Oliveira Fernandes E. 2014: SINPHONIE project. Guidelines for healthy environments within European schools. European Comission. Luxemburg: Európai Unió Kiadói Irodája. ISBN 978-92-79-39151-4. p. 1-94. https://publications.jrc.ec.europa.eu/repository/handle/JRC87071

3. Health Effects of School Environment (HESE). Final Scientific Report, Siena, Italy, January, 2006. Available online at: http://ec.europa.eu/health/ ph_projects/2002/pollution/fp_pollution_2002 frep_04.pdf Accessed: August 13, 2020.

4. Geiss O, Giannopoulos G, Tirendi S, Barrero-Moreno J, Larsen BR, Kotzias D. The AIRMEX study - VOC measurements in public buildings and schools/kindergartens in eleven European cities: Statistical analysis of the data. Atmos. Environ. 2011;45(22):3676-3684. https://doi.org/10.1016/j.atmosenv.2011.04.037

5. Kotzias D, Geiss O, Tirendi S, Barrero-Moreno J, Reina V, Gotti A, Cimino-Reale B, Marafante E, Sarigiannis D. Exposure to multiple air contaminants in public buildings, schools and kindergartens - the European indoor air monitoring and exposure assessment (AIRMEX) study. Fresenius Environ. Bull. 2009;18:670-681

6. Csobod E, Rudnai P, Vaskövi E. School Environment and Respiratory Health of Children (Search). International research project report within the programme "Indoor air quality in European schools: Preventing and reducing respiratory diseases", Szentendre, Hungary, February, 2010. Available online at: http://search.rec.org/searcht/ doc/SEARCH\%20publication_EN_final.pdf Accessed: August 13, 2020.

7. Beregszászi T, Burali A, Calzoni J, Colaiacomo E, Csobod E, Kocic A, Magyar Z, De Maio F, Moscato U, Nemeth G, Neri M, Poscia A, Prokai R, Rudnai P, Sinisi L, Szuppinger P, Varro M, Vaskovi E. Making Schools Healthy: Meeting Environment and Health Challenges. Final publication of the SEARCHII project. Budapest: Typonova;2013, p. 62. http:// search.rec.org/publications/making-schools-heal- 
thy-meeting-environment-and-health-challenges $/ 200$

8. Csobod E, Annesi-Maesano I, Carrer P, Kaphalopoulos S, Madureira J, Rudnai P, de Oliveira Fernandes E. SINPHONIE: Schools Indoor Pollution \& Health Observatory Network in Europe - final report. EUR 26738, Publications Office of the European Union, Luxembourg, 2014

9. Baloch RM, Maesano CN, Christoffersen J, et al. Indoor air pollution, physical and comfort parameters related to schoolchildren's health: Data from the European SINPHONIE study. Sci. Total Environ. 2020;739:139870. https://doi.org/10.1016/j. scitotenv.2020.139870

10. Annesi-Maesano I, Hulin M, Lavaud F, Raherison C, Kopferschmitt C, de Blay F, Charpin DA, Denis C. Poor air quality in classrooms related to asthma and rhinitis in primary schoolchildren of the French 6 Cities Study. Thorax. 2012;67(8):682-688. https://doi.org/10.1136/thoraxjnl-2011-200391

11. Forns J, Dadvand P, Foraster M, Alvarez-Pedrerol M, Rivas I, López-Vicente M, Suades-Gonzalez E, Garcia-Esteban R, Esnaola M, Cirach M, Grellier J, Basagaña X, Querol X, Guxens M, Nieuwenhuijsen MJ, Sunyer J. Traffic-Related Air Pollution, Noise at School, and Behavioral Problems in Barcelona Schoolchildren: A Cross-Sectional Study. Environ. Health Perspect. 2016;124(4):529-535. https://doi. org/10.1289/ehp.1409449

12. Madureira J, Paciência I, Rufo J, Ramos E, Barros H, Teixeira JP, de Oliveira Fernandes E. Indoor air quality in schools and its relationship with children's respiratory symptoms. Atmos. Environ. 2015;118:145-156. $\quad$ https://doi.org/10.1016/j.atmosenv.2015.07.028

13. Villanueva F, Tapia A, Lara S, Amo-Salas M. Indoor and outdoor air concentrations of volatile organic compounds and $\mathrm{NO}_{2}$ in schools of urban, industrial and rural areas in Central-Southern Spain. Sci. Total Environ. 2018;622-623:222-235. https://doi. org/10.1016/j.scitotenv.2017.11.274

14. WHO (World Health Organization). WHO Guidelines for Indoor Air Quality: Selected Pollutants. Copenhagen: WHO Regional Office for Europe; 2010. https://apps.who.int/iris/handle/10665/260127
15. Uhde E, Salthammer T. Impact of reaction products from building materials and furnishings on indoor air quality-A review of recent advances in indoor chemistry. Atmos. Environ. 2007;41(15):3111-3128. https://doi.org/10.1016/j.atmosenv.2006.05.082

16. Wolkoff P, Nielsen GD. Effects by inhalation of abundant fragrances in indoor air - An overview. Environ. Int. 2017;101:96-107. https://doi.org/10.1016/j. envint.2017.01.013

17. Ribéron J, Derbez M, Lethrosne M, Kirchner S. Impact of airing behaviour on air stuffiness in schools and daycare centres: Development of a specific tool for ventilation management, 12th International conference on indoor air quality and climate, Austin (USA), June 5-10, 2011.

18. Batterman S. Review and Extension of $\mathrm{CO}_{2}$-Based Methods to Determine Ventilation Rates with Application to School Classrooms. International Journal of Environmental Research and Public Health 2017;14(2), 145. https://doi.org/10.3390/ijerph74020145

19. Carrer P, de Oliveira Fernandes E, Santos H, Hänninen $\mathrm{O}$, Kephalopoulos S, Wargocki P. On the Development of Health-Based Ventilation Guidelines: Principles and Framework. Int J Environ Res Public Health, 2018 Jul; 15(7): 1360. https:// doi:10.3390/ijerph15071360

20. Marzocca A., Di Gilio A., Farella G., Giua R., De Gennaro G. 2017: Indoor Air Quality Assessment and Study of Different VOC Contributions within a School in Taranto City, South of Italy. Environ. 4. 23. p. 1-11. https://doi.org/10.3390/environments 4010023

21. Morawska L, Afshari A, Bae GN, Buonanno G, Chao $\mathrm{CYH}$, Hänninen $\mathrm{O}$, Hofmann W, Isaxon C, Jayaratne ER, Pasanen P, Salthammer T, Waring M, Wierzbicka A. Indoor aerosols: from personal exposure to risk assessment. Indoor Air. 2013;23(6):462-487. https://doi.org/70.11717/ina.12044

22. IPCHEM. The European Commission's information platform for chemical monitoring data. 2015. Available online at: http://ipchem.jrc.ec.europa.eu/Accessed: April 6, 2020. 